\title{
UNIVERSITYOF
}

FORWARD

THINKING

WESTMINSTER用

WestminsterResearch

http://www.westminster.ac.uk/westminsterresearch

Digital platforms: customer satisfaction, eWOM and the moderating role of perceived technological innovativeness

Ruiz-Alba, J.L., Abou-Foul, M., Nazarian, A. and Foroudi, P.

This article is ( $\odot$ Emerald and permission has been granted for this version to appear here: http://westminsterresearch.westminster.ac.uk/

Emerald does not grant permission for this article to be further copied/distributed or hosted elsewhere without the express permission from Emerald Group Publishing Limited.

The final, published version in Information Technology \& People, DOI: 10.1108/itp-072021-0572, 2021 is available at:

https://doi.org/10.1108/itp-07-2021-0572

This manuscript version is made available under the CC-BY-NC-ND 4.0 licence https://creativecommons.org/licenses/by-nc-nd/4.0/

The WestminsterResearch online digital archive at the University of Westminster aims to make the research output of the University available to a wider audience. Copyright and Moral Rights remain with the authors and/or copyright owners. 


\section{Digital platforms: customer satisfaction, eWOM and the moderating role of perceived}

technological innovativeness

[Accepted for publication (07/11/2021) in Information, Technology \& People]

(Authors' version)

Ruiz-Alba, José L. University of Westminster, (London, UK).

Abou-Foul, Mohamad. University of West London (London, UK).

Nazarian, Alireza. University of Westminster, (London, UK).

Foroudi, Pantea. Middlesex University London, (London, UK).

Abstract

Purpose- This paper aims to investigate how customer satisfaction can be achieved in the context of digital platform services, its influence on eWOM and how such relationships can be moderated by perceived technological innovativeness (PTI)

Design/methodology/approach- The research framework was developed and empirically tested using an online survey and analysed using structural equation modelling (SEM). Data were gathered from 501 Uber customers in London, UK.

Findings- This study recognises and confirms that trust and cost saving enhanced customer satisfaction in Uber mobility services, which has a positive impact on eWOM. There are other findings regarding users who share rides versus those who do not share. Furthermore, it has been found that PTI moderates the relationship between customer satisfaction and eWOM.

Originality/value- This research draws on collaborative consumption literature and contributes to the antecedents of customer satisfaction in digital economy literature: trust, environmental impact, cost saving and utility. The study offers an empirical validation of the role of PTI in enhancing eWOM. This paper breaks new ground for a better understanding of how PTI can moderate the influence of customer satisfaction and eWOM in digital platforms.

Keywords: eWOM; Customer satisfaction; digital platforms; perceived technological innovativeness

Paper type- Research paper.

\section{Introduction}

Collaborative consumption gained popularity after the 2008 global financial crisis, regarded as a turning point of the development of the sharing economy, which is closely related to the evolution of information technology (IT) (Wang and Wang, 2020). The sharing economy has been conceptualised as "ICT-enabled platforms for exchanges of goods and services drawing on non-market logics such as sharing, lending, gifting and swapping as well as market logics 
such as renting and selling" (Laurell and Sandström, 2017, p. 63). Digital solutions have made consumers able to link openly with a large range of goods and services (Geissinger et al., 2020). One of the most paradigmatic companies in the sharing economy is Uber. They define themselves as a technology platform that uses a huge network and leading technology (Uber, 2019). Uber is widely regarded as an innovative company providing mobility services within their ridesharing platform and operates in more than 10,000 cities across the globe in 69 countries and \$65bn gross bookings with 111 million Monthly Active Platform Consumers ('MAPCs') and seven billion trips per year (Uber, 2019). It operates in a highly competitive and rapidly transforming ecosystem while recognizing that innovation in platform solutions and IT is crucial for sustaining competitive advantage (Uber, 2019). Uber has identified five operating segments, one of which is 'rides', which will be the context investigated in this research. Apart from routing and payment technologies, at the core of Uber's technologies are the marketplace technologies, which include demand prediction, matching/dispatching and pricing technologies. As they state in their fiscal annual report, "We intend to continue to invest in new platform offerings that we believe will further strengthen our platform and existing offerings" (Uber, 2019, p.5). However, given this solid declaration of intentions, it is relevant to know how the company is perceived by customers regarding their technological innovativeness and potential future innovation and how this perception can moderate the relationships between customers/users' satisfaction and other behaviours such as eWOM. Brand recognition is critical for their success due to heavy competition (Uber, 2019). In fact, the \#DeleteUber campaign resulted in hundreds of thousands of consumers who stopped using Uber's platform. At the core of Uber's strategy is to "serve the customer experience, enabling us to attract new platform users and to deepen engagement with existing platform users" (Uber, 2019, p.5).

The technology expands the development of new service offerings, but also, from a subjective point of view, consumers' perceptions about the ease of use and perceived value of the sharing systems are crucial (Lu et al., 2019). Although researchers are showing increased interest in understanding customers' perception of platform technological innovativeness (Akhmedova, et al., 2021), much of the extant literature is limited and widely narrow in scope in terms of methodological approach, theoretical underpinnings, market segmentation and, more importantly, the nature of the digital information platforms. Customer perception of a specific platform's capabilities plays a key role in opinion formation and is considered a key enabler to accept or reject innovation (Peltier et al., 2020). 
Considering the popularity of sharing economy platforms in recent years and the importance of customer satisfaction and loyalty in success and survival of these platforms (Akhmedova, et al., 2021; Mas-Machuca et al., 2021), the importance of eWOM in collaborative consumption context has been proven to be highly important in generating brand equity, customer loyalty, firm credibility, customer engagement, shaping consumer expectations and purchase decisions; it also helps in addressing the agency problem intertied in the platform exchange (Vermeer et al., 2019). It is, therefore, crucial for both academics and practitioners to pay attention to the concept of eWOM and customer satisfaction in sharing economy platforms. However, having said that, the empirical research on customer satisfaction and collaborative consumption online channels is not fully developed (Huarng and Yu, 2019). Also, more importantly, the anecdotal evidence in this line of inquiry suggests that platform companies have redefined the customer experience, engagement and motivation (Xu and Lee, 2020).

Technology acceptance and adoption also have a crucial role in platform success. Recently personal innovativeness in information technologies has been investigated as a moderator of relevant relationships (Abubakre et al., 2020) and also the moderating role of technology and how it can strengthen satisfaction has been studied in different contexts (James et al., 2021). Also, technology experience has received attention demonstrating a strong influence of personal innovativeness (Thompson et al., 2006) and the perceived ease of use has been found to be a critical element for technology adoption (Venkatesh et al., 2003). Recently, Mancha and Shankaranarayanan (2021), investigated digital innovativeness in a platform context concluding that some platform businesses such as Uber can be considered as "digital innovators" in their successful execution of digital business models (Mancha and Iyer, 2017). However, the literature which investigates the perception of the product innovativeness and product familiarity (Calantone et al., 2006) hinted at a trade-off between high level of perceived product innovativeness and product familiarity, placing new technological advancement in jeopardy if customers reject the technological platform capabilities for overengineering and sophisticated configurations. Therefore, the rapid development of technologies and the process that leads to customers' technology acceptance requires a thorough understanding in an ever-evolving knowledge-based economy. Consequently, empirical research is needed to understand the relationships between the antecedents of customer satisfaction, perceived technological innovativeness and consequences on customer behaviour. 
The concept of perceived technological innovativeness is critical because the industries in which these platforms compete are characterised by quick technological developments. Customers will engage better with firms' new technological solutions through research and development ('R\&D ') or acquisition of third-party technologies (Gawer 2021). It is interesting to note that, in 2018, Uber's R\&D accounted for $13 \%$ of costs and expenses while, in 2019, they substantially increased to $34 \%$ (Uber, 2019, p.65).

Although research on platform innovation exists, the current discourse of literature mainly focuses on impact of customer satisfaction on eWOM (Bueno and Gallego, 2021). The focus of this body of research is on the characteristics of digital platforms that enhance customer satisfaction and, in return, eWOM. There is, however, scant research highlighting the role perceived technological innovativeness plays within the marketing field (Thakur et al., 2016). Consequently, our research model is built around and extending frameworks put forward by Donio'et al. (2006), Kim et al. (2009) and Möhlmann (2015) to analyse the relationship existing between the customer satisfaction, trust, cost saving, and, at the end, customer eloyalty in the form of eWOM. In this research, the authors have extended those frameworks to encapsulate more relevant constructs related to CC adhering to scholars' call (see Zhang et $a l ., 2018$ ) to assess the impact of environmentally friendly technologies and policies in such a setting and explore the relationship existing between customer utility and customer satisfaction.

Additionally, empirical studies contributing to collaborative consumption literature highlighted the factors that influence customer adoption, such as perceived financial benefits, ease of use, service quality, and trust and how it leads to digital brand equity (Benoit et al., 2017; Ozbal et al., 2020). More empirical evidence is required, to shed more light on antecedents of customer satisfaction in digital platforms such as Uber and its impact of eWOM. Therefore, the main aim of this research is to explain the customer satisfaction effect on eWOM in a CC context. Building on the research's empirical results, the paper strives to draw practical implications for transport mobility solutions provided by Uber.

Furthermore, this research contributes to the current body of research by developing, integrating and empirically testing a model of customer satisfaction in a collaborative consumption context, and goes beyond constructs used in current literature (Donio' et al., 2006). More specifically, this research tests the construct of perceived technological innovativeness and examines its moderation role between customer satisfaction and eWOM. 
The research question for the paper is: what are the antecedents and consequences of customer satisfaction of Uber mobility users? The answer to this question will have significant implications for digital platform managers and sharing economy developers. 


\section{Literature Review}

\subsection{Collaborative consumption}

In this context, collaborative consumption can be conceptualised as a medium of creating economic activities by harnessing the access of underutilised resources for those economic entities who are willing to share their resources or expertise for profit or non-profit purposes. Hamari et al. (2016, p.4) define collaborative consumption as "the peer-to-peer-based activity of obtaining, giving, or sharing the access to goods and services, coordinated through community-based online services". Collaborative consumption is embedded within the "sharing economy" (Barnes and Mattsson, 2016). These authors conducted a Delphi study in order to identify drivers, inhibitors and directions for future development of collaborative consumption economic motives, with cost saving being another important area that they identified; indeed, economic drivers are most important, followed by technological and social/cultural drivers. Word of mouth is also another important driver in collaborative consumption (Stephen and Toubia, 2010). Environmental was one of the main areas that they identified in particular to reduce environmental pollution, but surprisingly environmental concern (sustainability) was considered of minor importance; however, this current study will include this variable as antecedent of satisfaction with the use of Uber platform due to the concern with environmental pollution (Botsman and Rogers, 2011). Also cost saving, utility and trust have been proven to be solid antecedents of customer satisfaction in the context of a sharing economy (Möhlmann, 2015). Electronic word of mouth (eWOM) has also been identified as a key element in the context of a sharing economy (Hawapi et al., 2017; Zuo et al., 2019).

The advancement in IT-based solution and technology platforms facilitates the sharing economy platforms; this concept is often used interchangeably with collaborative consumption (Hamari et al., 2016). Collaborative consumption as a business model can also be viewed as a non-ownership model in which the exchange partners can rely on internet technological platforms to exchange a service or product (Belk, 2014). Collaborative consumption can also be viewed as a triangle of participants: first a platform provider (e.g., Uber), second a peer service provider (e.g., an Uber driver) and third a customer. What glues the supply and demand together is the platform provider (Benoit et al., 2017). In the same vein, the sharing economy concept can be decomposed to three main components each with unique features and configurations. 
First, the access economy that arranges the exchange of second-hand goods economy, such as the eBay platform; second, the community-based economy which advances the discourse of social benefits and collaborative projects and community empowerment, such as Wikipedia (Oliveira et al., 2020). Finally, the platform economy that enables the exchange of goods and services through technology-based platforms such as Uber (Acquier et al., 2017).

The research paper is focused on CC platforms which act merely as economical-technological coordination providers who operate to create socioeconomic as well as technological values to the exchange partners by fostering shared access to products rather than owning them (Hamari et al., 2016). The debate about collaborative consumption has highlighted its environmental, social and economic impacts; the environmental impact of CC can manifest in users favouring access and availability of resources over ownership, this act can help in reducing greenhouse gas emission and framing the corresponding problem of climate change and circular economy (Gallego-Schmid et al., 2020).

While the social promise of CC can help customers access better and cheaper services and leverage solidarity, and social bonding among community users (Benkler, 2016), it has been critiqued by some scholars for lack of accountability, transparency, ethics and appropriate government regulation (Slee, 2017).

Research has found that a positive encounter with digital platforms reduces customers' level of anxiety and provokes real-time opinion sharing, which is used as a proxy to measure customer satisfaction (Griffith et al., 2018). Customer satisfaction can also play a mediator role between customer trust and eWOM (Oliveira et al., 2020). Another important initiator and driver for overall customer satisfaction is customer dependency on digital services in terms of regular usage and service familiarity. The aspect of product innovativeness from a customer perspective is referred to as customer discontinuity, which requires a behaviour change to adapt to the new innovation (McNally et al., 2010); a high level of discontinuity may hinder customer acceptance and increase negative eWOM. The most recent $\mathrm{CC}$ literature stressed the importance of customers' behavioural intention and loyalty in terms of eWOM (Clauss et al., 2019). Bankole and Bankole, (2017) also found that customer satisfaction in $\mathrm{CC}$ enhances customers' behavioural intention to recommend and participate in positive eWOM.

Various recent studies have extended the Theory of Acceptance and Use of Technology UTAUT (Venkatesh et al., 2012) and highlighted an important construct that fits the new development of a sharing economy. In the context of carsharing platforms, Curtale et al. (2021) found social influence is the main driver of behavioural intention, followed by 
performance expectancy and personal attitude while trust did not affect the customers' behavioural intention. On a similar note, Tran et al.'s (2019) study of electric carsharing platforms also applied UTAUT in examining customer acceptance, and the study concluded that hedonic motivation and product familiarity have the highest positive impact on customer behavioural intention to use carsharing platforms. Fleury et al.'s (2017) study of corporate carsharing applied UTAUT and found little support for the service's perceived environmental friendliness on behavioural intentions, while performance expectancy has the highest impact on users' acceptability. Studies on eWOM in collaborative consumption settings (see Möhlmann, 2015; Zuo et al., 2019) also highlighted the role of trust as an important antecedent of customer satisfaction and a source of social capital. Trust and mutual reciprocity are also proven to promote behavioural intention, while pro-environmental attitude has a positive effect on intention to accept carsharing platforms and help in building social capital (Crucke and Slabbinck, 2019).

\section{2 eWOM}

The evaluation of a service is a complex process that has different consequences, one of which is the desire of the service user to share their experience with others. The intention to influence other customers' decisions does not need to be always present, but the fact is that sharing experiences can definitively influence others' perception and behaviours. When the experience is shared using online channels, the capacity of influence is huge regardless of the main types used: positive, negative and neutral (Vermeer et al., 2019).

The concept of eWOM emerged from the traditional Word of Mouth (WOM) that was conceptualised as "informal communications directed at other consumers about the ownership, usage, or characteristics of particular goods and services or their sellers" (Westbrook, 1987, p. 261).

Even though WOM still exists, there is a consensus that, with the proliferation of social media channels, WOM is being overtaken by eWOM (Hennig-Thurau et al., 2004), which is defined by Hennig-Thurau et al. (2004 p.39) as "any positive or negative statement made by potential, actual or former customers about a product or company, which is made available to a multitude of people and institutions via Internet". In that sense, eWOM allows service users to gather information from other users regarding their experience within a few seconds (Resnick et al., 2000) and refers to the communication among the customers of service users via the Internet (Cheung and Thadani, 2012). It is important to understand how eWOM is 
influenced by personal relations (Hsu et al., 2013) as service users consider the information provided by peers in social media.

Platforms are not exempt from this phenomenon. In fact, platform providers' reputation is considered critical, especially during the service delivery and customer interaction with the platform supply end. Therefore, a business which considers customer engagement in a positive experience in online reviews is a huge business value (Benoit et al., 2017).

Word of mouth is aslo an important aspect that influences customers decision-making, and prior studies hinted at a link between eWOM and trust in building social capital in terms of cognitive resources and relational resources (Nahapiet and Ghoshal, 1998) in which platform users collectively generate stronger ties by interaction on a digital platforms in which they share mutual interests and a shared language (Gvili and Levy, 2018). eWOM can strengthen individuals' social ties for those who seek to maintain and increase their social capital (Valenzuela et al., 2009). In this context, eWOM can take three forms. First, opinion giving such as sharing a usage experience that might influence the user's social connection perception and invoke discussion. Second, eWOM can also manifest in opinion seeking such as looking for advice or consultation from other users on social networks. Finally, opinion passing such as sharing information about new service promotion or new technological advancement (Norman and Russell, 2006; Chu and Kim, 2011). However, one individual can be a combination of the three aspects of eWOM: opinion leader, seeker and transmitter.

\section{Theoretical Background and Hypotheses}

\subsection{Customer trust and satisfaction}

This study conceptualises trust following Morgan and Hunt (1994, p.32), wherein they found that trust exists when "one party has confidence in an exchange partner's reliability and integrity". This willingness to have confidence and reliance in an exchange partner is a cornerstone in building trust and helps customers to build the behavioural intention of labelling an exchange partner as trustworthy (Moorman et al., 1993), and the perception of safeness and security during use or transaction (Wirtz and Lwin, 2009). In collaborative consumption ecosystems, trust can be conceptualised as a mechanism with a triadic nature in which customers trust the platform provider and service provider (service user $\leftrightarrow$ platform $\leftrightarrow$ service provider) (Ozbal et al., 2020).

In respect to digital economy platforms, companies gain more market power, which entails ensuring the welfare of their customers and working to generate trust through perceived 
credibility and benevolence (Doney and Cannon, 1997; Slee, 2017), Chai, Malhotra and Alpert (2015) found a significant positive relationship between trust and satisfaction in highly ethically responsible digital platforms.

Parallel to this, Keymolen (2013) found that digital companies need to be trusted on issues such as privacy and control, and digital platforms need to respect customer preferences on what data are collected, and how they are handled to deliver personalised services, which leads to an institutional structure designed to leverage both customer trust and satisfaction. Trust and satisfaction can also be generated if customers have a feeling that the digital business practices are labelled as transparent and accessible, in which terms of use and disclosures are understandable and lead to the delivery of quality services and enhanced customer satisfaction. Hartl and Hofmann (2021) found a positive impact of trust on customer satisfaction, stressing that digital services should be wrapped with the latest technology to keep the digital services secure and reliable. Finally, trust is found to be a powerful predictor of customer satisfaction and loyalty in carsharing platforms (Ma et al., 2020). Following this line of reasoning, this study proposes trust as a conceptual antecedent of customer satisfaction.

\section{Hypothesis 1: Customer trust is positively related to satisfaction}

\subsection{Company environmental impact and satisfaction}

This study follows Banerjee's (2002 p.181) definition of environmental impact where it is defined as "the organization-wide recognition of the legitimacy and importance of the biophysical environment in the formulation of organization strategy, and the integration of environmental issues into the strategic planning process". This conceptualisation takes into consideration both perspectives of external stakeholders and the internal perspective on integration of environmental issues into a firm's strategic plans. Carsharing platforms can help in reducing $\mathrm{CO}_{2}$ emission substantially resulting from a reduction in car ownership, congestion, pollution and energy consumption (Migliore et al., 2020). Hartl et al.'s (2018) found a positive relationship between sustainable impact of carsharing with usage intention in a peer-to-peer $(\mathrm{P} 2 \mathrm{P})$ usage context.

Prud'homme and Raymond (2013) found a positive relationship between the adoption of sustainable development and customer satisfaction in the hotel industry. In the same vein, Hamari et al. (2016) indicated a significant positive relationship between sustainability and customer satisfaction, especially for customers with altruistic values towards consumption and the ecosystem (De Groot and Steg, 2007). This relationship was also proven by Gerdt et 
al. (2019), whereby their study found a relationship between sustainability orientation and customer satisfaction. Furthermore, De Mendonca and Zhou's (2019) empirical findings support a significant association between companies' environmental performance and customer satisfaction. This leads to the following hypothesis:

Hypothesis 2: Environmental impact is positively related to customer satisfaction

\subsection{Cost saving and customer satisfaction}

Cost saving is defined as the reduction of service or product costs with the aim to increase customer value (Lamberton and Rose, 2012). The economics of information have paved the way to lower the transaction costs and increase the economies of scale, which, in return, can lead to cheaper services or products; the perception that the customer is getting the best offer in the market can lead to customer satisfaction and loyalty (Möhlmann, 2015). The cost saving associated with using platform business can help in endorsing the individual's selfbenefit. Prior research has proven that cost saving is a key determinant of customer satisfaction in the digital and sharing economy (Mont, 2004; Möhlmann, 2015); customers can cut the initial cost of investment in mobility solutions by relying on mobility platforms, in which a service provides cost structure built on availability and service usage. This cost reduction structure was found to be a key factor influencing customer usage, satisfaction and customer loyalty (Moeller and Wittkowski, 2010; Spann et al., 2018).

Bardhi and Eckhardt's (2012) findings suggest that cost saving was a better determinant of customer satisfaction than ethical and environmental policies, while platform pricing policies are key in building long-term relationships with customers. Platforms that provide means for customers to cut day-to-day expenses enjoyed higher customer participation and involvement, which leads to satisfaction (Grewal et al., 2012; Reisman et al., 2019). Thus, this study proposes the following hypothesis.

Hypothesis 3: Cost saving is positively related to customer satisfaction.

\subsection{Utility and customer satisfaction.}

According to Childers et al. (2001), utility can be conceptualised as the ease and the convenience in both access and speed in consuming a desired market offering; it also can be viewed as providing an experience that minimises the investment in both time and effort.

Therefore, in understanding utility in a platform business, it is paramount to highlight the various sources of utility and from where it stems. First, utility can stem from the transaction itself, in which customers perceive the use of a platform is superior in terms of deal value to 
other alternative options (Lamberton and Rose, 2012); second, utility can be manifested in terms of better offer flexibility, such as mobility utility, ownership reduction and accessibility (Fritze et al., 2020). Utility can also come in the form of social utility in which the user of a digital platform may receive an approval from reference groups (Lamberton and Rose, 2012). Overall, utility can be distinguished as a basic and add-on utility; the former can be conceptualised as closely related to the core service in which the market offer is helping in solving a particular problem for the customer (Liberman et al., 2004), while add-on utility can manifest in providing relational, social and emotional change to customers pre- and postconsumption.

Möhlmann (2015) found a positive relationship between utility in a platform context and customer satisfaction. Furthermore, empirical evidence suggests that platforms which maximise benefits relative to costs, increased customer knowledge, achieved higher positive customer attitude, customer satisfaction and a positive digital customer experience (MingSung Cheng et al., 2009; Foroudi et al., 2018). Following this reasoning, the study postulates the following hypothesis.

Hypothesis 4: Utility has a positive effect on customer satisfaction.

\subsection{Customer satisfaction and eWOM}

Oliver (1997) defines customer satisfaction, as a "consumer's fulfilment response. It is a judgment that a product or service feature, or the product or service itself, provides (or is providing) a pleasurable level of consumption related fulfilment, including levels of under- or over-fulfilment" (Oliver, 1997, p.13). In marketing literature, customer satisfaction is widely viewed as the cognitive ability and the emotional tendency of the customer to subjectively evaluate the desired service with the actual service received.

The extant literature empirically investigating the relationship between satisfaction and eWOM found a positive relationship between them (Serra-Cantallops et al., 2018). Customer satisfaction is also considered a reliable indicator for positive eWOM; customers encountering a more positive digital platform experience are more enticed to become loyal and spread warmer eWOM (Lii and Lee, 2012). Based on this argumentation and rationale, the following hypothesis is postulated:

Hypothesis 5: Customer satisfaction has a positive effect on eWOM generation 


\subsection{Moderating effects of perceived technological innovativeness}

This study defines perceived technological innovativeness as "the perceived degree of newness and improvement over existing alternatives" (Lowe and Alpert, 2015, p.4); therefore, this construct can typically be distinguished either by technology novelty or market novelty, service superiority to customer and adoption difficulty to customer (Lee and O'Connor, 2003). Therefore, the platform market offering should be perceived as innovative by the consumers for the digital platform to achieve the sought return from innovation (Anselmsson and Johansson, 2009).

Innovation literature has indicated that firms that emphasise their technological superiority in their ads, leads to better customer communication and better return on their innovation-driven ventures (Simon and Honore Petnji Yaya, 2012); therefore, platform companies also need to highlight the overall improved customer benefits resulted from platform technological innovativeness. Research also shows that customers of companies with new superior market technology had a better online engagement and were more eager to advocate the service providers' technology and benefits (Gruen et al., 2006).

Product development literature argued that new product advantages can be leveraged by enhancing the level of product or service innovativeness to the limit, which does not hamper customer satisfaction and eWOM (Calantone et al., 2006). Dou et al. (2021) found that companies have the tendency to compete through an array of novel design and technologies embedded in new service platforms that complicate both customer interaction and ease of use, resulting in a drop in customer emotional engagement and satisfaction as a result of technology usage frustration. Therefore, we argue that customers' technology familiarity is paramount to enhance the perception of useful platform innovativeness (Dai et al., 2015).

In terms of the link between the perceived innovativeness of services and customer satisfaction, Stock (2011) found an inverted S-shaped relationship between service innovation and customer satisfaction; the perception of innovativeness can enhance customer conviction that the platform company can fulfil and exceed customer expectations and, thus, enhance customer satisfaction (Alexander et al., 2008).

The characteristic of a platform's technological innovativeness is important for platform firms to be more efficient, this, in return, can help in early customer problem identification and solution to optimise resource mobilisation. Platforms that use AI technologies to optimise customer services by cutting time and prices can lead to a better consumption journey, customer satisfaction and enhancing loyalty (Prentice et al., 2020). 
Previous research on perceived technological innovativeness indicates not only its direct impact on customer satisfaction and purchase intention, but also its moderating role; for instance, consumers with higher PTI show a greater level of satisfaction and online engagement in eWOM (Hwang and Griffiths, 2017). These effects are based on consumer innovativeness that can be materialised by the belief that the individual online narrative can create some impact (Gruen et al., 2006). Consistent with these findings and based on the literature, this research paper argues that, in a collaborative consumption context, satisfaction impact on eWOM can be amplified by the level of customer perception of platform innovativeness, Hence, it is posited:

\section{Hypothesis 6:}

Perceived technological innovativeness exhibited by consumers moderates the relationship between customer satisfaction and eWOM. Specifically, the relationship diminishes under conditions of low perceived technological innovativeness and becomes stronger as perceived technological innovativeness increases.

Table I: Formal definitions of the constructs.

\begin{tabular}{|c|c|c|}
\hline $\begin{array}{l}\text { Construct } \\
\text { (Abbreviation) }\end{array}$ & Operational Definition & Source \\
\hline $\begin{array}{l}\text { Customer } \\
\text { Trust (CT) }\end{array}$ & $\begin{array}{l}\text { Willingness to rely on an exchange partner in whom one } \\
\text { has confidence }\end{array}$ & $\begin{array}{l}\text { (Moorman et al., } \\
\text { 1993, p. 82). }\end{array}$ \\
\hline $\begin{array}{l}\text { Customer } \\
\text { Satisfaction } \\
\text { (CS) }\end{array}$ & $\begin{array}{l}\text { A judgment that a product or service feature, or the } \\
\text { product or service itself, provided (or is providing) a } \\
\text { pleasurable level of consumption-related fulfilment, } \\
\text { including levels of under-or over fulfilment }\end{array}$ & $\begin{array}{l}\text { (Oliver 1997, p. } \\
\text { 13). }\end{array}$ \\
\hline $\begin{array}{l}\text { Environmental } \\
\text { Impact (EI) }\end{array}$ & $\begin{array}{l}\text { Corporate environmentalism is the organization-wide } \\
\text { recognition of the legitimacy and importance of the } \\
\text { biophysical environment in the formulation of } \\
\text { organization strategy, and the integration of } \\
\text { environmental issues into the strategic planning process. }\end{array}$ & $\begin{array}{l}\text { (Banerjee, 2002, } \\
\text { p.181) }\end{array}$ \\
\hline $\begin{array}{ll}\text { Cost } & \text { Saving } \\
\text { (CS) }\end{array}$ & $\begin{array}{l}\text { reducing service or product costs with the aim to } \\
\text { increase customer value }\end{array}$ & $\begin{array}{l}\text { (Lamberton and } \\
\text { Rose, 2012) }\end{array}$ \\
\hline Utility (UT) & $\begin{array}{l}\text { a consumer's overall assessment of the product or } \\
\text { service based on perceptions on what is received (in } \\
\text { terms of extra benefits and values that the customer } \\
\text { expects to get in using it) and what is given }\end{array}$ & $\begin{array}{l}\text { (Zeithaml, 1988, } \\
\text { p. 14). }\end{array}$ \\
\hline eWOM & $\begin{array}{l}\text { all informal communications directed at consumers } \\
\text { through Internet based technology related to the usage } \\
\text { or characteristics of particular goods and services, or } \\
\text { their sellers." }\end{array}$ & $\begin{array}{l}\text { (Litvin et al., } \\
\text { 2008, p. 461) }\end{array}$ \\
\hline
\end{tabular}




\begin{tabular}{|l|l|l|}
\hline $\begin{array}{l}\text { Perceived } \\
\text { Technological } \\
\text { Innovativeness } \\
\text { (PTI) }\end{array}$ & $\begin{array}{l}\text { the perceived degree of newness and improvement over } \\
\text { existing alternatives. }\end{array}$ & $\begin{array}{l}\text { (Lowe and Alpert, } \\
\text { 2015, p. 4) }\end{array}$ \\
\hline
\end{tabular}

\subsection{A conceptual model for satisfaction antecedents, eWOM and moderating role of} perceived technological innovativeness

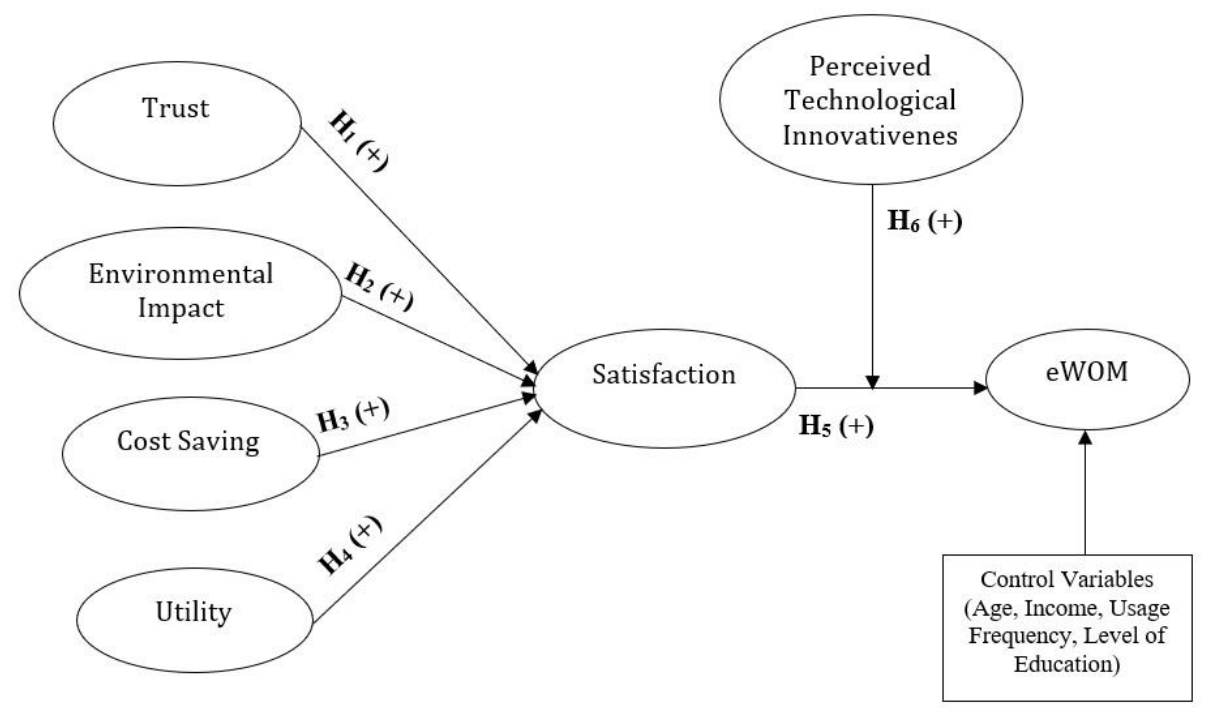

Figure 1: The Research model.

\section{Research Methodology}

\subsection{Sample and data collection}

The study uses non-probability convenience sampling and snowballing techniques (Bryman and Bell, 2011). The sample frame consists of users of Uber mobility service in London. Uber is a good example of the peer-to-peer offering of services and is not a consumer-toconsumer sharing of products (Jiang and Tian, 2018). In the online mobility and ride hailing services, UBER is the largest and leading global provider with a market share of $37.2 \%$ in 2019 (UBER, 2019); therefore, it makes its users the ideal sample to be examined. For inclusion, participants in the survey should have a high degree of social media engagement and be using Uber mobility service on a regular basis. This helped in ensuring the validity of our data and that we had isolated the correct subjects for this study. To determine the minimum sample size required for robust PLS-SEM, we followed Hair et al.'s (2014: p 21), sample size recommendation in PLS-SEM for a statistical power of $80 \%$, an alpha of 0.05 and 
an effect size of 0.15 . Our final data set consists of 501 subjects, meeting and exceeding the minimum sample size of 85 recommended.

A cross-sectional, self-administered survey was used to collect the study data. The study questionnaire was developed in English. The main survey was conducted and distributed online via an online survey specialist platform. In all, the study collected 501 fully usable questionnaires, with a response rate of $25 \%$ in line with another similar research response rate (Wagner et al., 2012).

Table 2 represents the respondents' demographic characteristics and profiles. Over half of the sample, 52\%, were male, the respondents were highly educated (more than $92 \%$ have a university degree), while $82 \%$ of subjects have used Uber mobility service on a weekly or daily basis and $97 \%$ of respondents were highly active on social media and content creation platforms.

Table II: Descriptive data and Demographic profile of respondents ( N=501)

\begin{tabular}{|c|c|c|c|c|c|c|c|}
\hline & & Frequency & Percent & & & Frequency & Percent \\
\hline \multicolumn{4}{|l|}{ Gender } & \multicolumn{4}{|l|}{ Age } \\
\hline & Female & 240 & 48 & & Under 18 & 0 & 0 \\
\hline & Male & 261 & 52 & & $\begin{array}{l}18-24 \\
\text { years old }\end{array}$ & 228 & 45.5 \\
\hline \multicolumn{4}{|c|}{ Level of education } & & $\begin{array}{l}25-34 \\
\text { years old }\end{array}$ & 104 & 20.7 \\
\hline & $\begin{array}{l}\text { High school } \\
\text { education }\end{array}$ & 29 & 5.7 & & $\begin{array}{l}35-44 \\
\text { years old }\end{array}$ & 101 & 20 \\
\hline & $\begin{array}{l}\text { Bachelor's } \\
\text { degree }\end{array}$ & 228 & 45.5 & & $\begin{array}{l}45-54 \\
\text { years old }\end{array}$ & 51 & 10 \\
\hline & $\begin{array}{l}\text { Master's } \\
\text { degree }\end{array}$ & 161 & 32 & & $55+$ & 17 & 3.8 \\
\hline & $\begin{array}{l}\text { Professional } \\
\text { degree }\end{array}$ & 19 & 3.8 & \multicolumn{4}{|c|}{ Uber usage frequency } \\
\hline & $\begin{array}{l}\text { Doctorate } \\
\text { degree }\end{array}$ & 58 & 11.6 & & Daily & 169 & 33.7 \\
\hline & Others & 6 & 1.4 & & Weekly & 243 & 48.5 \\
\hline \multicolumn{4}{|l|}{ Income } & & Monthly & 73 & 14.5 \\
\hline & $\begin{array}{l}\text { Less than } \\
£ 20,000\end{array}$ & 136 & 27 & & $\begin{array}{l}\text { Less than } \\
\text { once a } \\
\text { month }\end{array}$ & 16 & 3.3 \\
\hline
\end{tabular}




\begin{tabular}{|c|c|c|c|c|c|c|}
\hline & $£ 20,000$ to & 141 & 28 & \multicolumn{3}{|c|}{ Level of social media engagement } \\
\hline & $\begin{array}{l}£ 35,000 \text { to } \\
£ 49,999\end{array}$ & 74 & 14.8 & High & 487 & 97.2 \\
\hline & $\begin{array}{l}f 50,000 \text { to } \\
f 74,999\end{array}$ & 111 & 22 & Medium & 5 & 1 \\
\hline & $\begin{array}{l}£ 75,000 \text { to } \\
£ 99,999\end{array}$ & 32 & 6.4 & Low & 9 & 1.8 \\
\hline & $\begin{array}{l}\text { Over } \\
£ 100,000\end{array}$ & 7 & 1.8 & & & \\
\hline \multicolumn{4}{|c|}{ Ride Mode } & & & \\
\hline & Shared & 218 & 43.5 & & & \\
\hline & Not shared & 283 & 56.5 & & & \\
\hline
\end{tabular}

In terms of non-response bias, the test results revealed no significant differences between early - responded within the first two weeks - and late respondents, suggesting that nonresponse bias was not a problem in this research (Armstrong and Overton, 1977).

\subsection{Measures}

This study's measures are shown along with their sources (Table 1). All of the scale items measurements were adopted from previous literature; but they were adapted for this study context; content validity and statistical reliability were established, ensuring reliability and validity for the construct development (Nunnally and Bernstein, 1995).

Preliminary data collection instrument was piloted to ensure its comprehensibility and cleanliness. Furthermore, an independent academic and industry experts panel of eight specialised in digital economy, marketing and information technology were approached, which ensured the questionnaire's face validity and constructs' conceptualisation while no major scale issues were reported. Finally, exploratory factor analysis was carried out to check the psychometric properties of the scale and the scale was refined and validated as to its statistical properties (Churchill and Iacobucci, 2002).

Furthermore, all of the study constructs were captured using latent reflective constructs (Edwards and Bagozzi, 2000), with direct measurement items on a seven-point Likert scale, ranging from 1 ('strongly disagree') to 7 ('strongly agree'). 


\subsection{Control variables}

To account for extraneous sources of variation in eWOM, we controlled this study model for the customer age, income and level for education following Engelbertink and van Hullebusch (2013) and Mittendorf (2018). We also controlled our model for usage frequency; Uber usage frequency refers to how often the platform has been used (usage time) and corresponds to the routinised mobility needs for the customer and the depth of consumption (Ram and Jung, 1990). Prior research findings suggest that the higher the consumption interaction between provider and customer, the higher the customer satisfaction and loyalty (Zeithaml et al., 1996).

\subsection{Psychometric properties of measurement scales}

The study measurement instrument has been assessed following Gerbing and Anderson's (1988) psychometric properties recommendations involving the assessment of content validity, reliability, discriminant validity, convergent validity, and scale dimensionality validity; the constructs' intercorrelation matrix is presented in Table 3.

\section{INSERT TABLE 3 HERE (See Appendix)}

The content validity of the study measurement scale was maintained through comprehensive structural face-to-face interviews with highly knowledgeable industry experts, such as marketing managers and IT experts. This formed the basis of the developed construct and the study's questionnaire.

All scales and constructs achieved an acceptable Cronbach's alpha above the threshold of 0.70 (Nunnally, 1978), establishing scale reliability and the constructs' unidimensionality (Nunnally and Bernstein, 1995). Constructs' unidimensionality was also assessed by calculating the AVEs of each construct where they all exceeded $>.50$, which adequately reflects unidimensionality (Fornell and Larcker, 1981).

In order to test our measures for discriminant validity, HTMT criterion was used, following recommendation from Henseler et al. (2015), and resulted in all disattenuated correlations between constructs less than the threshold of 0.85, thus establishing a good discriminant validity in the study's measures (Kline, 2011). In this regard, Table 4 shows the output from the HTMT test, establishing discriminant validity.

Anderson and Gerbing (1988) recommended establishing convergent validity by means of confirmatory factor analysis (CFA); the test resulted in all measurements items loading as significant at $p<.001$ and above 0.5 on its corresponding construct, establishing convergent validity. 


\begin{tabular}{|c|c|c|c|c|c|c|c|}
\hline & 1 & 2 & 3 & 4 & 5 & 6 & 7 \\
\hline \multicolumn{8}{|l|}{ 1. Cost Saving } \\
\hline 2. Environmental Impact & 0.76 & & & & & & \\
\hline 3. Perceived Technological Innovativeness & 0.74 & 0.69 & & & & & \\
\hline 4. Satisfaction & 0.69 & 0.77 & 0.83 & & & & \\
\hline 5.Trust & 0.82 & 0.77 & 0.84 & 0.74 & & & \\
\hline 6.Utility & 0.78 & 0.84 & 0.67 & 0.76 & 0.70 & & \\
\hline 7. eWOM & 0.74 & 0.64 & 0.81 & 0.70 & 0.71 & 0.58 & \\
\hline
\end{tabular}

Table IVV Heterotrait-Monotrait (HTMT) Criterion

\begin{tabular}{|c|c|c|c|c|c|c|c|}
\hline & 1 & 2 & 3 & 4 & 5 & 6 & 7 \\
\hline \multicolumn{8}{|l|}{ 1. Cost Saving } \\
\hline 2. Environmental Impact & 0.76 & & & & & & \\
\hline 3. Perceived Technological Innovativeness & 0.74 & 0.69 & & & & & \\
\hline 4. Satisfaction & 0.69 & 0.77 & 0.83 & & & & \\
\hline 5.Trust & 0.82 & 0.77 & 0.84 & 0.74 & & & \\
\hline 6.Utility & 0.78 & 0.84 & 0.67 & 0.76 & 0.70 & & \\
\hline 7. eWOM & 0.74 & 0.64 & 0.81 & 0.70 & 0.71 & 0.58 & \\
\hline
\end{tabular}

Table 5 shows the psychometric properties of measurement scales with factor loadings for all scale items and alpha coefficient, composite reliability, average variance extracted and Rsquared all in a satisfactory manner.

The study model's global validity, or 'goodness of fit' (GoF) was calculated using the following formula (Tenenhaus et al., 2005):

$$
\mathrm{GoF}=\sqrt{\oslash \text { Communality } \times \oslash R^{2} \text { inner }} .
$$

The study model yielded a GOF $=0.56$ and the result is deemed to satisfy Cohen's (2013) criterion for adequate, significant and very large effect size, providing good support for the fit of the study's model.

Table V: The domain and items of construct in extant literature, factor loadings, descriptive statistics, correlation, and reliabilities

\begin{tabular}{|l|l|l|l|l|l|l|l|}
\hline Construct & Item & $\begin{array}{l}\text { Factor } \\
\text { Loading }\end{array}$ & Mean & $\begin{array}{l}\text { Std. } \\
\text { Deviation }\end{array}$ & CR & AVE & $\mathrm{R}^{2}$ \\
\hline Trust (Moorman et al., 1993, p. 82) $\alpha .92$ & & 0.94 & 0.81 & \\
\hline \\
$\qquad$\begin{tabular}{ll|l|l|l|l|}
\hline \\
\hline
\end{tabular} \\
\hline
\end{tabular}




\begin{tabular}{|c|c|c|c|c|c|c|c|}
\hline & $\begin{array}{l}\text { Uber cares about its } \\
\text { customers }\end{array}$ & $0.88^{* * *}$ & 4.81 & 1.47 & \multirow[b]{4}{*}{0.92} & \multirow[b]{4}{*}{0.81} & \multirow[b]{4}{*}{0.84} \\
\hline & Uber is predictable. & $0.89^{* * *}$ & 5.11 & 1.31 & & & \\
\hline & I trust Uber & $0.90^{* * *}$ & 5.27 & 1.52 & & & \\
\hline \multicolumn{5}{|c|}{ Satisfaction (Benner, 2009) $\alpha .88$} & & & \\
\hline & $\begin{array}{l}\text { Overall, I am } \\
\text { satisfied with Uber } \\
\text { mobility service }\end{array}$ & $0.93^{* * *}$ & 5.30 & 1.67 & & & \\
\hline & $\begin{array}{l}\text { I am delighted with } \\
\text { Uber service. }\end{array}$ & $0.86^{* * *}$ & 4.81 & 1.36 & & & \\
\hline & $\begin{array}{l}\text { It is wise of me to } \\
\text { use Uber service. }\end{array}$ & $0.91^{* * *}$ & 5.27 & 1.32 & & & \\
\hline \multicolumn{5}{|c|}{$\begin{array}{l}\text { Environmental Impact (Lamberton and Rose, 2012; Moeller and } \\
\text { Wittkowski, 2010) } \alpha .89\end{array}$} & 0.93 & 0.81 & \\
\hline & $\begin{array}{l}\text { By using Uber, I } \\
\text { reduce my use of } \\
\text { natural resources. }\end{array}$ & $0.87^{* * *}$ & 4.58 & 1.39 & & & \\
\hline & $\begin{array}{l}\text { With the use of Uber } \\
\text { service, } \\
\text { demonstrate } \\
\text { environmental } \\
\text { friendly consumption } \\
\text { behaviour. }\end{array}$ & $0.93^{* * *}$ & 4.54 & 1.71 & & & \\
\hline & $\begin{array}{l}\text { When I use Uber, I } \\
\text { am contributing to } \\
\text { reduce air pollution. }\end{array}$ & $0.90^{* * *}$ & 4.67 & 1.67 & & & \\
\hline \multicolumn{5}{|c|}{ Cost Saving (Lamberton and Rose, 2012) $\alpha .88$} & 0.93 & 0.82 & \\
\hline & $\begin{array}{l}\text { For the given price, I } \\
\text { rate the Uber offer } \\
\text { as good. }\end{array}$ & $0.92^{* * *}$ & 5.42 & 1.45 & & & \\
\hline & $\begin{array}{l}\text { For the given quality } \\
\text { of the Uber service } \\
\text { offer, I rate the price } \\
\text { as } \\
\text { good. }\end{array}$ & $0.93^{* * *}$ & 5.21 & 1.34 & & & \\
\hline & $\begin{array}{l}\text { I save money using } \\
\text { Uber instead of black } \\
\text { cabs. }\end{array}$ & $0.85^{* * *}$ & 5.71 & 1.39 & & & \\
\hline \multicolumn{5}{|c|}{ Utility (Lamberton and Rose, 2012) $\alpha .86$} & 0.91 & 0.78 & \\
\hline & $\begin{array}{l}\text { I believe Uber offer } \\
\text { substitutes quite } \\
\text { well for an own car. }\end{array}$ & $0.88^{* * *}$ & 4.84 & 1.30 & & & \\
\hline & $\begin{array}{l}\text { Uber is better than } \\
\text { using an own car. }\end{array}$ & $0.89^{* * *}$ & 4.76 & 1.53 & & & \\
\hline & $\begin{array}{l}\text { Using Uber is useful } \\
\text { to save time. }\end{array}$ & $0.87^{* * *}$ & 5.16 & 1.36 & & & \\
\hline
\end{tabular}




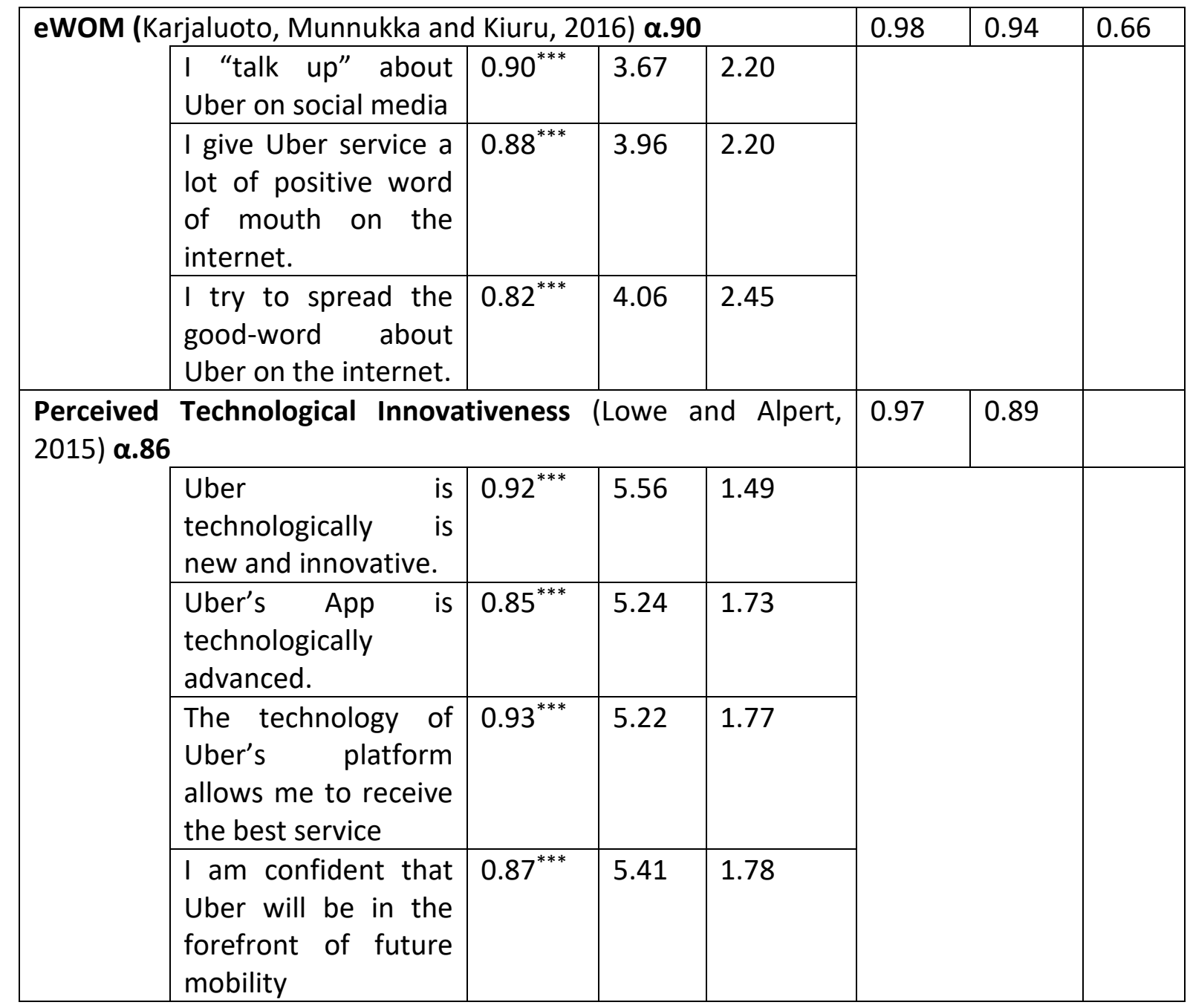

\subsection{Common method variance}

Common method variance (CMV) was investigated using Harman's single-factor test (Podsakoff and Organ, 1986). The results of the unrotated principal components factor analysis reveal no single dominant factor is present, with the largest factor produced only accounting for $27.5 \%$ of the total variance, adding more evidence that no potential common method bias exists in this study's results (Podsakoff and Organ, 1986).

\subsection{Structural model analysis and results}

The study tested the proposed model using structural equation modelling methodology with partial least squares (SEM-PLS) (Hair, 2010). The structural model estimation, Table 5, shows that trust and cost saving enhanced customer satisfaction in Uber mobility services, with path coefficients of $0.52(\mathrm{p}<0.001)$ and $0.35(\mathrm{p}<0.01)$, respectively, explaining 84\% of the variance in customer satisfaction. Customer satisfaction enhanced eWOM, with a path 
coefficient of 0.47 ( $p<0.001$ ), explaining $66 \%$ of the variance. Consequently, H1, H3 and H5 were supported as the path coefficients were significant at $\mathrm{p}<0.001$.

$\mathrm{H} 2$, environmental impact on customer satisfaction, and $\mathrm{H} 4$, utility impact on customer satisfaction, failed to be supported. $\mathrm{R}^{2}$ resulted for both dependant variables in the model were significant for both customer satisfaction and eWOM at $84 \%$ and $66 \%$, respectively, which resulted in a large effect size as calculated with $\mathrm{R}^{2}$ in which the effect size $\mathrm{f}^{2}>0.35$ for both endogenous variables (Cohen, 2013). With regard to control variables, income and level of education exert no significant impact on the study model as reported from the standardised PLS path coefficients estimation; however, both age and usage frequency impact on the dependent variable was significant with a path coefficient of $0.40(\mathrm{p}<0.001)$ and $0.37(\mathrm{p}<$ 0.001) respectively. Consequently, to make sure the significant results were not due to covariation with control variables, the study's model was tested with and without the inclusion of controlled variables and results appeared to be stable and independent of control variables without a significant increase in the variance explained in eWOM. See Figure 2.

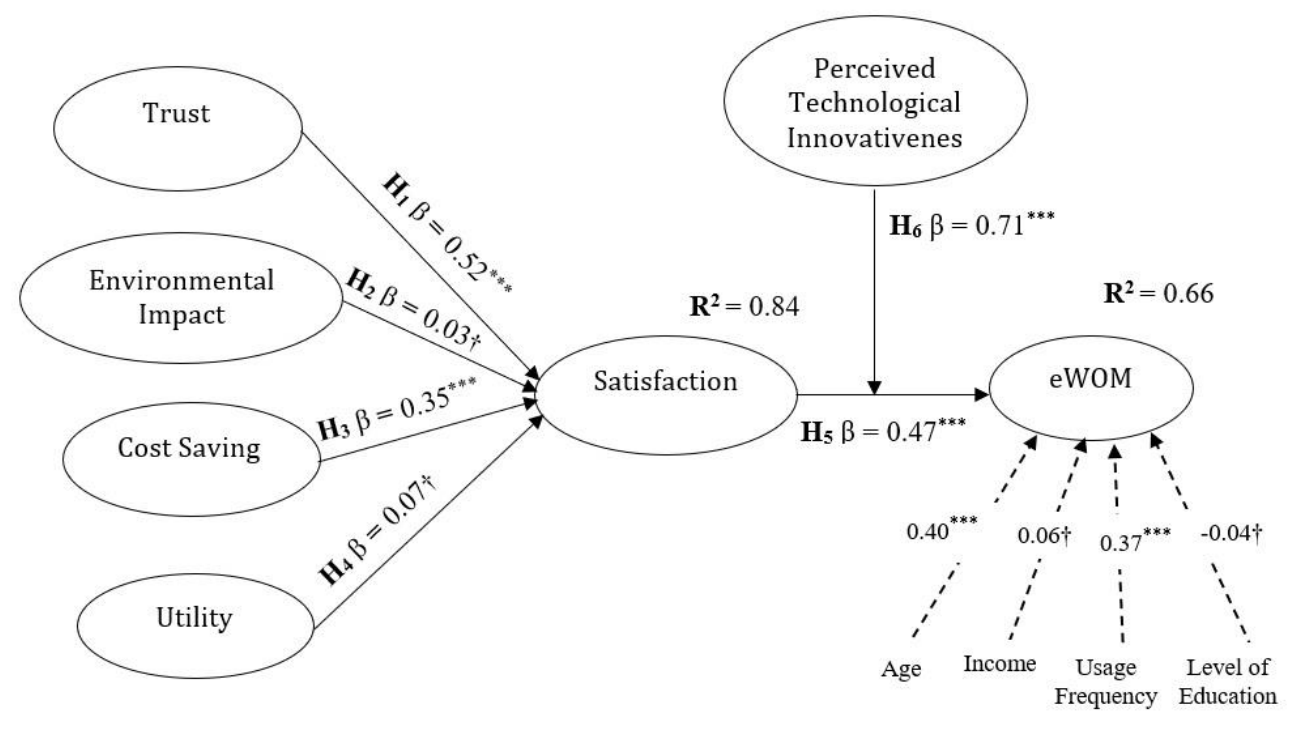

Figure 2: The results of the hypothesized model.

$$
\begin{aligned}
& + \text { Path is not significant. } \\
& { }^{* *} p<0.05 \\
& { }^{* * *} p<0.001
\end{aligned}
$$

\subsection{Group's comparison and analysis}

Group analyses were carried out using the same indicators for different groups, see Table 6 . Levene's test was used to carry out the group comparison (Sarstedt and Mooi, 2019) by means of bootstrapping to compare if the variances of the parameter estimates differ significantly between the study's groups. 
An interesting finding was that the t-values for the group comparison between users who share and users who don't share their rides showed significant differences $(p<0.05)$ between the following two paths in the structural models:

Satisfaction --- $\bigoplus--->$ eWOM: The influence of satisfaction on eWOM was found to be higher in users who shared their rides, $\beta=0.67$, versus users who don't, $\beta=0.42$.

Cost Saving --- $\bigoplus--->$ Satisfaction: The influence of cost saving on satisfaction was found to be higher in users who shared their rides, $\beta=0.43$, versus users who don't, $\beta=0.32$.

The study found that users who share their rides are more inclined to also share their experience on social media platforms, enhancing positive (eWOM), while users who don't usually share their rides are more conservative to talk up their experience on social media. We also found that youngsters are more open to share their experience across digital social media platforms.

The study also found a significant statistical difference between age groups (see Table 6) in terms of the moderator construct effect; in the young customer segment $<35$ years old (Akhmedova et al., 2021), perceived technological innovativeness has a higher impact on satisfaction, eWOM relationship, with $\beta=0.72$ versus older customer $\geq 35$ years segment with $\beta=0.55$ and the bootstrapping in the multigroup analysis was significant with $(\mathrm{p}<0.001)$. Furthermore, the impact of cost saving on customer satisfaction was higher $\beta=0.38$ for younger group compared with older group $\beta=0.24$ this relationship was also statistically significant. Finally the impact of trust on customer satisfaction was higher $\beta=0.55$ for older group compared with $\beta=0.50$ for younger group with $(p<0.001)$.

The study also unearthed a significant statistical difference between usage frequency of Uber groups (see Table 6), a group analysis between the heavy users of UBER service (daily and weekly) and light user segments (less than once a month), which yielded supporting evidence for the following relationships. First, the impact of trust on satisfaction was higher in the heavy user group, $\beta=0.32$, compared to $\beta=0.24$ for the lighter user group, with statistically significant difference between those sub groups. The impact of cost saving on customer satisfaction was higher, $\beta=0.41$, for the heavy user group and $\beta=0.30$ for light user group, which was statistically significant and different. Finally, the impact of satisfaction on eWOM was higher, $\beta=0.52$, for the heavy user group and $\beta=0.38$ for lighter user group with $(p<$ $0.001)$.

\subsection{Test for moderating effects}


Interactive moderating was tested following Chin et al. (2003). The result was significant (see Table 6) with a path coefficient of 0.25 ( $\mathrm{p}<0.001)$. The two-way interaction plotting also resulted in a positive moderating in which perceived technological innovativeness strengthened the positive relationship between customer satisfaction and eWOM (See Figure 3)

\section{INSERT TABLE 6 HERE (See Appendix)}

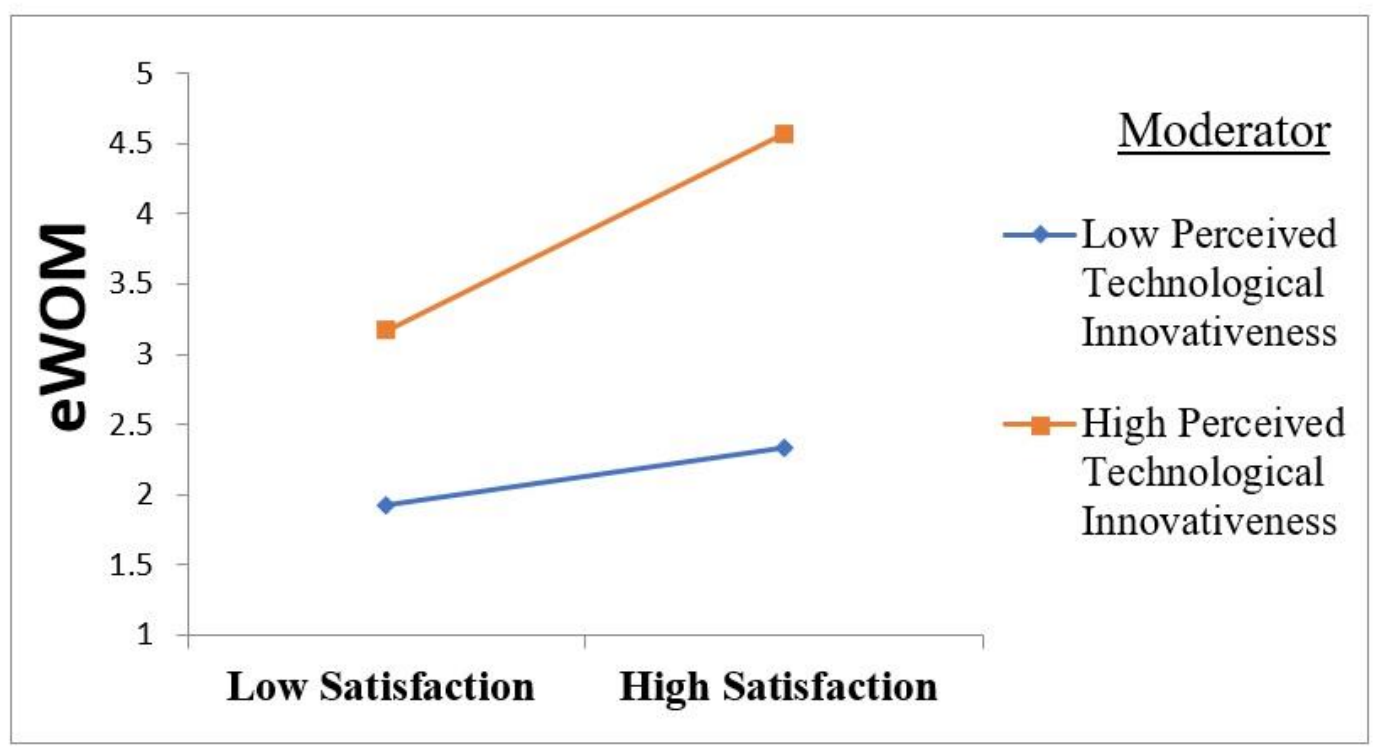

Figure 3: Moderation of perceived technological innovativeness between customer satisfaction and e-WOM

\section{Discussion}

This research paper developed and tested a theoretical model of the determinants of customer satisfaction in Uber mobility service and the consequences of such customer satisfaction. This study found that trust is a key determinant of customer satisfaction in a collaborative consumption setting in line with Hofmann et al. (2017), especially in a peer-to-peer consumption model in which the customer trusts both the digital platform company and the provider who owns the collaborative service (e.g., the Uber driver) (Martin, 2016; Wilhelms et al., 2017).

This study results also provide evidence that cost saving has a positive impact on customer satisfaction in platform services. This can be explained by the inclination of digital platform 
companies to provide fair and competitive pricing policies that associate with positive customer emotions, which leads to customer satisfaction (Tabibnia et al., 2008).

Consistent with previous literature (Thakur, 2019), this study's results validated the significant role of customer satisfaction in motivating platform users in spreading the eWOM, which can be a clear indicator of the ultimate customer loyalty. However, no significant association was found between the environmental impact and the utility impact on customer satisfaction, respectively, in line with studies (Hu et al., 2019) where they found no impact of green management policies adopted by sharing economy platforms on the intention to use sharing economy-based services or products. This interesting finding might be explained by customers' perception of green platforms to be inferior or overpriced, thus hindering satisfaction. However, these results contradict the findings of a positive relationship between green incentives and customer satisfaction (Hartl et al., 2018; Gerdt et al., 2019).

The results also did not support the hypothesis that platform utility would be positively related to customer satisfaction (Hennig-Thurau et al., 2004). This counterintuitive finding suggests that the specific nature of the digital economy in advancing the utility perception into the customer mind is changing and needs to be taken into consideration in the service development phase (Möhlmann, 2015).

The findings in comparing the study's sub-models revealed that users who are happy to share their ride with others, in both a financial way and ride sharing option, are also more inclined to share the experience online, parallel to Moeller and Wittkowski (2010) where they highlighted that sharing options are cheaper than non-sharing for those price conscious customers who are always on cost saving agendas. This type of social sharing and consumption can also lead to increased sales and profits (Menon et al., 2016).

The difference in the impact of perceived technological innovativeness in age groups could stem from the fact that younger people emphasise platform functionality and the platform price competitiveness. in line with Kong et al.'s (2019) findings that, in millennials age group, the technical aspects can help enhance eWOM and platform trust, emphasising the structural dimension of the social capital, while older group main focus was on trust and emotional aspect of their experience, in other words the rational aspect of the social capital in the exchange.

The study finding regarding the role of PTI in enhancing customer satisfaction and eWOM, is highly important, especially as it encapsulates the micro level of platform innovativeness that providers must address in terms of technical capabilities and marketing communication for different age groups. (Danneels and Kleinschmidt, 2001; Calantone et al., 2006). It's 
important that platform technological capabilities pose new and special features deemed to be innovative from the consumers' perspective; this view will ultimately enhance the new platform service performance in all dimensions. Perception of innovativeness is also important for younger age groups that emphasise product novelty and product excitement, that stimulate their adoption decision, fulfilling the younger generation's portrayed selfimage as more savvy, knowledgeable and intelligent (Fu and Elliott, 2013). Technological product consumer familiarity also plays a huge role in perception of innovativeness; the direct and indirect experience with various technological platforms gives the customer a benchmark to compare and contrast technological attributes, features and functionality (Calantone et al., 2006; Borgogno et al., 2015). Our study echoed this notion and highlighted that PTI of the Uber platform is strengthening the relationship between satisfaction and eWOM.

Our findings also highlighted that previous experience in technology platforms and usage frequency differ across experienced and inexperienced users, indicating that, the higher the frequency of platform usage, the higher customer satisfaction, service trust and ultimately participation in eWOM. This can be explained through the myopic search process, in which customers are inclined to adopt and reuse those familiar services that minimise time invested in learning and the behavioural change required (McNally et al., 2010).

\section{Conclusions}

\subsection{Theoretical contributions}

This current study contributes to the social capital theory through the relational resource embedded in the construct of trust and the cognitive resources of social capital through eWOM (Wang et al., 2016). Our findings indicate that frequent usage of platform service helps to strengthen network ties and trust by linking the structural and relational dimensions of SC (Wang et al., 2016). Leading to a greater customer satisfaction and enhancing customer knowledge in a sociointeractive fashion. This is in line with Sun et al.'s (2012) findings that social capital resources (relational and cognitive are drivers of customer satisfaction in an information technology context. It also enhances persuasion knowledge development and consumption-related advice manifested in using eWOM. Building on this study results, it can be argued that the positive association between customer satisfaction and eWOM can lead to the maintenance and creation of a social capital dialectical process that facilitates the 
exchange on the digital platform through building social ties, trust, and forming shared values between the platform productive resources (Chiu et al., 2006).

This study contributes to the body of literature that has shed some light of the antecedents of customer satisfaction in a CC context. Furthermore, it helped in advancing the concourse of current developments in the area of eWOM and the externalities that affect customer online participation.

To our knowledge, this is the first study that intends to understand the role of customer perception of technological innovativeness of the platform firms, in enhancing customer satisfaction throughout the consumption journey.

Another theoretical contribution of this research can be the introduction of the study's conceptual framework, that goes beyond the classical configuration in the literature of satisfaction antecedents and eWOM (Anderson and Srinivasan, 2003; Möhlmann, 2015) as these studies did not provide a holistic approach to the new emerging themes in management such as sustainability and technology in terms of relationships, configurations and interdependencies.

Further, the results of this study shed light on how perceived technological innovativeness and platform capabilities can increase technology acceptance and enhance customer perception of the platform expected performance and effort expectancy in term of utility and cost saving, facilitating the conditions necessary for knowledge exchange to occur (Ellison et al., 2007).

Finally, while some research has recognised the importance of satisfaction, eWOM relationship, the mechanisms by which satisfaction affects eWOM remain under examined, especially in the digital economy context where empirical evidence on this relationship is still very limited. Therefore, the model developed in this paper can serve as a theoretical basis for evaluation of such dynamism.

\subsection{Managerial implications}

This study introduces a practical implication and highly valuable actionable insights that can help managers to enhance customer satisfaction and eWOM for digital platform users and also IT specialists who want to understand more about their strategic technological investments.

First, by providing empirical evidence that customer satisfaction has a positive effect on eWOM, this study highlights that managers have to do more to enhance users' engagement and participation in forming a pleasant platform experience. Therefore, prudent managers 
should recognise the role trust and cost saving plays in enhancing customer satisfaction, which leads to better product positioning, social capital and network effect (Wirtz et al., 2019).

Second, the study emphasises the role perceived technological innovativeness plays in enhancing customer social engagement by means of eWOM. Managers could clearly communicate the digital platform technological capabilities through the right communication channels, to educate their prospective customers on the latest investments in capabilities and technological developments, reduce any technological uncertainties which might arise and differentiate platform technological capabilities from sector competitors. Findings also can help in deriving advertising strategy, especially when the platform service has clear advantages over other known alternatives. Relying on more functional ads with technical details can evoke positive feelings and enhance customer satisfaction in the young and technology savvy customer segment, while older platform customers can be targeted with more emotional ads strategy to highlight the benefit of using the platform and how service providers ensure customer safety and leverage trust (Kong et al., 2019).

Third, managers should encourage customer engagement with the platform service by developing a well-designed reward and referral incentive system and integrated communication strategy to capitalise on the usage frequency benefits, in terms of customer satisfaction, trust and cost saving, and ultimately positive eWOM. Additionally, managers could introduce effective sustainable consumption policies and platform governance to leverage customer trust. This was one of the main determinants of customer satisfaction in the digital ecosystem; therefore, this needs a cohesive and structural approach in advancing customer safety, privacy and addressing equality issues and streamlining customer feedback (Romanou, 2018).

Fourth, this study findings highlighted the importance of pricing policies on digital platforms; in that sense, managers need to effectively leverage the platform's utilitarian value through price, cost, or efficiency advantages (Täeuscher and Laudien, 2018). The cost-focused approach when designing and introducing more interactive services to platforms is important to enhance the affordability of the rides, especially for millennial customers, thereby leveraging social shopping and group participation.

Fifth, it is also of high importance to advance the platform's technological capabilities that can identify and remove the source of any counterfeited reviews, which might alter algorithmic ranking of the service and might impact the service quality and corrode consumer trust and platform credibility (Zhuang et al., 2018). 
Finally, platform managers should view their relationship with customers as a partnership, this probably would imply adopting sound policies that encourage customers to spread the eWOM, and support them in making personal recommendations within the platform, which helps to reduce the agency problem inherited in the online exchange (Pavlou et al., 2007).

\section{Limitations and Future Research Directions}

While this study strived to increase the research rigour, as with any empirical research endeavour, this current research has some limitations. First, the research model was tested using cross-sectional data and longitudinal studies should be considered to further test the study results.

Second, the empirical results of the model testing revealed that environmental impact and utility did not fit the nomological network of relationships proposed by the study model; therefore, further theoretical foundation and empirical evidence is needed to examine these relationships in the digital platform settings. Additionally, the online data collection instrument limits the generalisability of our research findings due to sampling and access issues (Wright, 2005). Furthermore, trust construct can be expanded to assess the different levels of trust possessed by platform users in terms of level of trust in platform providers and the actual ride hailing supplier, such as the drivers.

Third, our samples were heavily UK-based and future research should examine our findings in a broader sample of users in more geographical areas and using a broader array of assessment methods. Moreover, this study results may be generalised only to those platform services companies who operate in a peer-to-peer ridesharing business and, as such, the study results should be approached with care when extrapolated to other sharing economy platforms. Therefore, it is highly recommended to test the proposed model for other sharing economy services using different data sets to enhance the model's predictive power and generalisability.

Finally, the moderation effect of perceived technological innovativeness of a platform company proposed provides evidence to enhance the impact of customer satisfaction on eWOM, but this finding may pertain only to this specific research context. However, various technological capabilities have different effects on customer perception of innovativeness (Stoel and Muhanna, 2009), and there is no universal technological innovativeness profile that fits all digital platform companies. Therefore, future studies might investigate the effect of different types of technological innovativeness, platform capabilities and configurations on consumer perception of this construct. 


\section{Final Remarks}

Drawing on and extending the social capital and (UTAUT) perspective, this study posited and tested the relationships between, trust, cost advantage, environmental impact, utility, customer satisfaction, perceived technological innovativeness and eWOM under an Uber mobility context. The paper's basic premise is that perceived technological innovativeness is a catalyst and instrumental to eWOM participation, especially for the highly satisfied customer category. Based on a survey of 501 Uber customers, the study model was tested and supported.

This study contributes to the social capital literature as it is one of the first to investigate the customer digital narrative in the context of collaborative consumption and how technological advancement embedded in platform resources can lead to a better access and mobilisation of social capital in its three dimensions. The study findings clarify the effectiveness of trust and cost saving as the main two pillars to increase customer satisfaction, Moreover, this study extends digital platform research by providing a conceptual foundation to link customer satisfaction to customers' eWOM. This study hopes that the theoretical framework and the empirical findings yielded provide a useful starting point for future empirical studies that investigate the satisfaction and eWOM relationship from a technological and social perspective. 


\section{References}

Abubakre, M., Zhou, Y. and Zhou, Z. (2020) 'The impact of information technology culture and personal innovativeness in information technology on digital entrepreneurship success', Information Technology \& People, ahead-of-print(ahead-of-print). doi: 10.1108/ITP-012020-0002.

Acquier, A., Daudigeos, T. and Pinkse, J. (2017) 'Promises and paradoxes of the sharing economy: An organizing framework', Technological Forecasting and Social Change, 125, pp. 1-10. doi: https://doi.org/10.1016/j.techfore.2017.07.006.

Akhmedova, A., Marimon, F. and Mas-Machuca, M. (2020) 'Winning strategies for customer loyalty in the sharing economy: A mixed-methods study', Journal of Business Research, 112, pp. 33-44. doi: https://doi.org/10.1016/j.jbusres.2020.02.046.

Alexander, D. L., Lynch, J. G. and Wang, Q. (2008) 'As Time Goes By: Do Cold Feet Follow Warm Intentions for Really New versus Incrementally New Products?', Journal of Marketing Research, 45(3), pp. 307-319. doi: 10.1509/jmkr.45.3.307.

Anderson, J. C. and Gerbing, D. W. (1988) 'Structural equation modeling in practice: A review and recommended two-step approach.', Psychological bulletin, 103(3), p. 411.

Anderson, R. E. and Srinivasan, S. S. (2003) 'E-satisfaction and e-loyalty: A contingency framework', Psychology \& Marketing, 20(2), pp. 123-138. doi: https://doi.org/10.1002/mar.10063.

Anselmsson, J. and Johansson, U. (2009) 'Retailer brands and the impact on innovativeness in the grocery market', Journal of Marketing Management, 25(1-2), pp. 75-95. doi: $10.1362 / 026725709 \times 410043$.

Armstrong, J. S. and Overton, T. S. (1977) 'Estimating Nonresponse Bias in Mail Surveys', Journal of Marketing Research, 14(3), pp. 396-402. doi: 10.1177/002224377701400320.

Banerjee, S. B. (2002) 'Corporate environmentalism: the construct and its measurement', Journal of Business Research, 55(3), pp. 177-191. doi: https://doi.org/10.1016/S01482963(00)00135-1.

Bankole, F. O. and Bankole, O. O. (2017) 'The effects of cultural dimension on ICT innovation: Empirical analysis of mobile phone services', Telematics and Informatics, 34(2), pp. 490-505.

Bardhi, F. and Eckhardt, G. M. (2012) 'Access-based consumption: The case of car sharing', Journal of consumer research, 39(4), pp. 881-898.

Barnes, S. J. and Mattsson, J. (2016) 'Understanding current and future issues in collaborative consumption: A four-stage Delphi study', Technological Forecasting and Social Change, 104, pp. 200-211. doi: https://doi.org/10.1016/j.techfore.2016.01.006.

Belk, R. (2014) 'You are what you can access: Sharing and collaborative consumption online', Journal of Business Research, 67(8), pp. 1595-1600. doi: https://doi.org/10.1016/j.jbusres.2013.10.001. 
Benkler, Y. (2016) 'Peer production, the commons, and the future of the firm', Strategic Organization, 15(2), pp. 264-274. doi: 10.1177/1476127016652606.

Benoit, S. et al. (2017) 'A triadic framework for collaborative consumption (CC): Motives, activities and resources \& capabilities of actors', Journal of Business Research, 79, pp. 219227. doi: https://doi.org/10.1016/j.jbusres.2017.05.004.

Borgogno, M. et al. (2015) 'The role of product familiarity and consumer involvement on liking and perceptions of fresh meat', Food Quality and Preference, 44, pp. 139-147. doi: https://doi.org/10.1016/j.foodqual.2015.04.010.

Botsman, R. and Rogers, R. (2011) What's mine is yours : how collaborative consumption is changing the way we live. London: HarperCollins.

Bryman, A. and Bell, E. (2011) Business research methods. 3rd ed. Oxford: Oxford Univ. Press.

Bueno, S. and Gallego, M. D. (2021) 'eWOM in C2C Platforms: Combining IAM and Customer Satisfaction to Examine the Impact on Purchase Intention', Journal of Theoretical and Applied Electronic Commerce Research, 16(5), pp. 1612-1630.

Calantone, R. J., Chan, K. and Cui, A. S. (2006) 'Decomposing product innovativeness and its effects on new product success', Journal of Product Innovation Management, 23(5), pp. 408-421.

Cheng, C. et al. (2019) 'The Influence of Leader Encouragement of Creativity on Innovation Speed : Findings from SEM and fsQCA', pp. 1-17.

Cheung, C. M. K. and Thadani, D. R. (2012) 'The impact of electronic word-of-mouth communication: A literature analysis and integrative model', Decision Support Systems, 54(1), pp. 461-470. doi: https://doi.org/10.1016/j.dss.2012.06.008.

Childers, T. L. et al. (2001) 'Hedonic and utilitarian motivations for online retail shopping behavior', Journal of Retailing, 77(4), pp. 511-535. doi: https://doi.org/10.1016/S00224359(01)00056-2.

Chin, W. W., Marcolin, B. L. and Newsted, P. R. (2003) 'A Partial Least Squares Latent Variable Modeling Approach for Measuring Interaction Effects: Results from a Monte Carlo Simulation Study and an Electronic-Mail Emotion/Adoption Study', Information Systems Research, 14(2), pp. 189-217. Available at: http://www.jstor.org/stable/23011467.

Chiu, C.-M., Hsu, M.-H. and Wang, E. T. G. (2006) 'Understanding knowledge sharing in virtual communities: An integration of social capital and social cognitive theories', Decision Support Systems, 42(3), pp. 1872-1888. doi: https://doi.org/10.1016/j.dss.2006.04.001.

Chu, S.-C. and Kim, Y. (2011) 'Determinants of consumer engagement in electronic wordof-mouth (eWOM) in social networking sites', International Journal of Advertising, 30(1), pp. 47-75. doi: 10.2501/IJA-30-1-047-075.

Churchill, G. and Iacobucci, D. (2002) Marketing research: Methodological foundations, 8th ed., Southwestern Publishing Co, Cincinatti, $\mathrm{OH}$. 
Clauss, T., Harengel, P. and Hock, M. (2019) 'The perception of value of platform-based business models in the sharing economy: determining the drivers of user loyalty', Review of Managerial Science, 13(3), pp. 605-634. doi: 10.1007/s11846-018-0313-0.

Cohen, J. (2013) 'Statistical Power Analysis for the Behavioral Sciences.' Hoboken: Taylor and Francis. Available at: http://www.123library.org/book_details/?id=107447.

Crucke, S. and Slabbinck, H. (2019) 'An Experimental Vignette Study on the Attractiveness of Ownership-Based Carsharing Communities: A Social Capital Theory Perspective', Environment and Behavior, 53(4), pp. 379-408. doi: 10.1177/0013916519888969.

Curtale, R., Liao, F. and van der Waerden, P. (2021) 'User acceptance of electric car-sharing services: The case of the Netherlands', Transportation Research Part A: Policy and Practice, 149, pp. 266-282. doi: https://doi.org/10.1016/j.tra.2021.05.006.

Dai, H. et al. (2015) 'Explaining consumer satisfaction of services: The role of innovativeness and emotion in an electronic mediated environment', Decision Support Systems, 70, pp. 97-106. doi: https://doi.org/10.1016/j.dss.2014.12.003.

Dale Stoel, M. and Muhanna, W. A. (2009) 'IT capabilities and firm performance: A contingency analysis of the role of industry and IT capability type', Information \& Management, 46(3), pp. 181-189. doi: https://doi.org/10.1016/j.im.2008.10.002.

Danneels, E. and Kleinschmidtb, E. J. (2001) 'Product innovativeness from the firm's perspective: Its dimensions and their relation with project selection and performance', Journal of Product Innovation Management: An International Publication of the Product Development \& Management Association, 18(6), pp. 357-373.

Doney, P. M. and Cannon, J. P. (1997) 'An Examination of the Nature of Trust in BuyerSeller Relationships', Journal of Marketing, 61(2), pp. 35-51. doi: 10.1177/002224299706100203.

Donio', J., Massari, P. and Passiante, G. (2006) 'Customer satisfaction and loyalty in a digital environment: an empirical test', Journal of Consumer Marketing, 23(7), pp. 445-457. doi: 10.1108/07363760610712993.

Dou, R. et al. (2021) 'How can manufacturers make decisions on product appearance design? A research on optimal design based on customers' emotional satisfaction', Journal of Management Science and Engineering, 6(2), pp. 177-196. doi: https://doi.org/10.1016/j.jmse.2021.02.010.

Edwards, J. R. and Bagozzi, R. P. (2000) 'On the nature and direction of relationships between constructs and measures.', Psychological methods, 5(2), pp. 155-174. doi: 10.1037/1082-989x.5.2.155.

Ellison, N. B., Steinfield, C. and Lampe, C. (2007) 'The benefits of Facebook "friends:" Social capital and college students' use of online social network sites', Journal of computermediated communication, 12(4), pp. 1143-1168.

Engelbertink, A. and van Hullebusch, S. (2013) 'The effects of education and income on consumers' motivation to read online hotel reviews', Research in Hospitality Management, 2(1-2), pp. 57-61. doi: 10.1080/22243534.2013.11828292. 
Fleury, S. et al. (2017) 'What drives corporate carsharing acceptance? A French case study', Transportation Research Part F: Traffic Psychology and Behaviour, 45, pp. 218-227. doi: https://doi.org/10.1016/j.trf.2016.12.004.

Fornell, C. and Larcker, D. F. (1981) 'Evaluating Structural Equation Models with Unobservable Variables and Measurement Error', Journal of Marketing Research, 18(1), pp. 39-50. doi: 10.1177/002224378101800104.

Foroudi, P. et al. (2018) 'Investigating the effects of smart technology on customer dynamics and customer experience', Computers in Human Behavior, 80, pp. 271-282. doi: https://doi.org/10.1016/j.chb.2017.11.014.

Fritze, M. P. et al. (2020) 'Access-Based Services as Substitutes for Material Possessions: The Role of Psychological Ownership', Journal of Service Research, 23(3), pp. 368-385. doi: 10.1177/1094670520907691.

Fu, F. Q. and Elliott, M. T. (2013) 'The Moderating Effect of Perceived Product Innovativeness and Product Knowledge on New Product Adoption: An Integrated Model', Journal of Marketing Theory and Practice, 21(3), pp. 257-272. doi: 10.2753/MTP10696679210302.

Gallego-Schmid, A. et al. (2020) 'Links between circular economy and climate change mitigation in the built environment', Journal of Cleaner Production, 260, p. 121115. doi: https://doi.org/10.1016/j.jclepro.2020.121115.

Gawer, A. (2021) 'Digital platforms' boundaries: The interplay of firm scope, platform sides, and digital interfaces', Long Range Planning, 54(5), p. 102045. doi:https://doi.org/10.1016/j.lrp.2020.102045.

Geissinger, A. et al. (2020) 'Assessing user perceptions of the interplay between the sharing, access, platform and community-based economies', Information Technology \& People, 33(3), pp. 1037-1051. doi: 10.1108/ITP-12-2019-0649.

Gerbing, D. W. and Anderson, J. C. (1988) 'An Updated Paradigm for Scale Development Incorporating Unidimensionality and Its Assessment', Journal of Marketing Research, 25(2), pp. 186-192. doi: 10.2307/3172650.

Gerdt, S.-O., Wagner, E. and Schewe, G. (2019) 'The relationship between sustainability and customer satisfaction in hospitality: An explorative investigation using eWOM as a data source', Tourism Management, 74, pp. 155-172. doi: https://doi.org/10.1016/j.tourman.2019.02.010.

Grewal, D. et al. (2012) 'Retail Value-Based Pricing Strategies: New Times, New Technologies, New Consumers', Journal of Retailing, 88(1), pp. 1-6. doi: https://doi.org/10.1016/j.jretai.2011.12.001.

Griffith, D. A., van Esch, P. and Trittenbach, M. (2018) 'Investigating the mediating effect of Uber's sexual harassment case on its brand: Does it matter?', Journal of Retailing and Consumer Services, 43, pp. 111-118. doi: https://doi.org/10.1016/j.jretconser.2018.03.007.

de Groot, J. I. M. and Steg, L. (2007) 'Value Orientations to Explain Beliefs Related to Environmental Significant Behavior: How to Measure Egoistic, Altruistic, and Biospheric 
Value Orientations', Environment and Behavior, 40(3), pp. 330-354. doi: 10.1177/0013916506297831.

Gruen, T. W., Osmonbekov, T. and Czaplewski, A. J. (2006) 'eWOM: The impact of customer-to-customer online know-how exchange on customer value and loyalty', Journal of Business Research, 59(4), pp. 449-456. doi: https://doi.org/10.1016/j.jbusres.2005.10.004.

Gvili, Y. and Levy, S. (2018) 'Consumer engagement with eWOM on social media: the role of social capital', Online Information Review, 42(4), pp. 482-505. doi: 10.1108/OIR-052017-0158.

Hair, J. et al. (2014) 'Partial least squares structural equation modeling (PLS-SEM)', European Business Review, 26(2), pp. 106-121. doi: 10.1108/EBR-10-2013-0128.

Hair, J. F. (2010) Multivariate data analysis : a global perspective. Upper Saddle River, N.J.; London: Pearson Education.

Hamari, J., Sjöklint, M. and Ukkonen, A. (2016) 'The sharing economy: Why people participate in collaborative consumption', Journal of the Association for Information Science and Technology, 67(9), pp. 2047-2059. doi: https://doi.org/10.1002/asi.23552.

Hartl, B. et al. (2018) "Sustainability is a nice bonus" the role of sustainability in carsharing from a consumer perspective', Journal of Cleaner Production, 202, pp. 88-100. doi: https://doi.org/10.1016/j.jclepro.2018.08.138.

Hartl, B. and Hofmann, E. (2021) 'The social dilemma of car sharing - The impact of power and the role of trust in community car sharing', International Journal of Sustainable Transportation, pp. 1-24. doi: 10.1080/15568318.2021.1912224.

Hawapi, M. W. et al. (2017) 'Effects of Perceived Risks, Reputation and Electronic Word of Mouth (E-WOM) on Collaborative Consumption of Uber Car Sharing Service', IOP Conference Series: Materials Science and Engineering, 215, p. 12019. doi: 10.1088/1757$899 x / 215 / 1 / 012019$.

Hennig-Thurau, T. et al. (2004) 'Electronic word-of-mouth via consumer-opinion platforms: What motivates consumers to articulate themselves on the Internet?', Journal of Interactive Marketing, 18(1), pp. 38-52. doi: https://doi.org/10.1002/dir.10073.

Henseler, J., Ringle, C. M. and Sarstedt, M. (2015) 'A new criterion for assessing discriminant validity in variance-based structural equation modeling', Journal of the Academy of Marketing Science, 43(1), pp. 115-135. doi: 10.1007/s11747-014-0403-8.

Hofmann, E., Hartl, B. and Penz, E. (2017) 'Power versus trust - what matters more in collaborative consumption?', Journal of Services Marketing, 31(6), pp. 589-603. doi: 10.1108/JSM-09-2015-0279.

Hsu, Y. A. et al. (2013) 'Social Relationship Factors Influence on EWOM Behaviors in Social Networking Sites: Empirical Study: Taiwan and Vietnam', in.

$\mathrm{Hu}$, Jiayao et al. (2019) 'Do green practices really attract customers? The sharing economy from the sustainable supply chain management perspective', Resources, Conservation and Recycling, 149, pp. 177-187. doi: https://doi.org/10.1016/j.resconrec.2019.05.042. 
Huarng, K.-H. and Yu, M.-F. (2019) 'Customer satisfaction and repurchase intention theory for the online sharing economy', Review of Managerial Science, 13(3), pp. 635-647. doi: 10.1007/s11846-018-0321-0.

Huntingford, C. et al. (2019) 'Machine learning and artificial intelligence to aid climate change research and preparedness Machine learning and artificial intelligence to aid climate change research and preparedness'.

Hwang, J. and Griffiths, M. A. (2017) 'Share more, drive less: Millennials value perception and behavioral intent in using collaborative consumption services', Journal of Consumer Marketing, 34(2), pp. 132-146. doi: 10.1108/JCM-10-2015-1560.

James, T. L. et al. (2021) 'The moderating effect of technology overload on the ability of online learning to meet students' basic psychological needs', Information Technology \& People, ahead-of-print(ahead-of-print). doi: 10.1108/ITP-03-2021-0225.

Jiang, B. and Tian, L. (2018) 'Collaborative consumption: Strategic and economic implications of product sharing', Management Science, 64(3), pp. 1171-1188.

Keymolen, E. (2013) 'Trust and technology in collaborative consumption. Why it is not just about you and me', Bridging distances in technology and regulation, pp. 135-150. Available at: https://pure.uvt.nl/portal/files/1519132/TP2013_boek_19d.pdf\#page=136.

Kim, D. J., Ferrin, D. L. and Rao, H. R. (2009) 'Trust and Satisfaction, Two Stepping Stones for Successful E-Commerce Relationships: A Longitudinal Exploration', Info. Sys. Research, 20(2), pp. 237-257. doi: 10.1287/isre.1080.0188.

Kline, R. B. (2011) 'Principles and practice of structural equation modeling'. New York: Guilford Press.

Kong, Y. et al. (2020) 'In Sharing Economy We Trust: Examining the Effect of Social and Technical Enablers on Millennials' Trust in Sharing Commerce', Computers in Human Behavior, 108, p. 105993. doi: https://doi.org/10.1016/j.chb.2019.04.017.

Lamberton, C. P. and Rose, R. L. (2012) 'When is Ours Better than Mine? A Framework for Understanding and Altering Participation in Commercial Sharing Systems', Journal of Marketing, 76(4), pp. 109-125. doi: 10.1509/jm.10.0368.

Laurell, C. and Sandström, C. (2017) 'The sharing economy in social media: Analyzing tensions between market and non-market logics', Technological Forecasting and Social Change, 125, pp. 58-65. doi: https://doi.org/10.1016/j.techfore.2017.05.038.

Lee, Y. and Colarelli O'Connor, G. (2003) 'The Impact of Communication Strategy on Launching New Products: The Moderating Role of Product Innovativeness', Journal of Product Innovation Management, 20(1), pp. 4-21. doi: https://doi.org/10.1111/15405885.t01-1-201002.

Liberman, N. et al. (2004) 'The pros and cons of temporally near and distant action.', Journal of personality and social psychology, 86(6), pp. 781-795. doi: 10.1037/0022-3514.86.6.781. 
Lii, Y. and Lee, M. (2012) 'The joint effects of compensation frames and price levels on service recovery of online pricing error', Managing Service Quality: An International Journal, 22(1), pp. 4-20. doi: 10.1108/09604521211198083.

Lowe, B. and Alpert, F. (2015) 'Forecasting consumer perception of innovativeness', Technovation, 45-46, pp. 1-14. doi: https://doi.org/10.1016/j.technovation.2015.02.001.

Lu, D., Lai, I. K. and Liu, Y. (2019) 'The Consumer Acceptance of Smart Product-Service Systems in Sharing Economy: The Effects of Perceived Interactivity and Particularity', Sustainability . doi: 10.3390/su11030928.

Ma, F. et al. (2020) 'The Influence of Continuous Improvement of Public Car-Sharing Platforms on Passenger Loyalty: A Mediation and Moderation Analysis', International Journal of Environmental Research and Public Health . doi: 10.3390/ijerph17082756.

Mancha, R. and Shankaranarayanan, G. (2021) 'Making a digital innovator: antecedents of innovativeness with digital technologies', Information Technology \& People, 34(1), pp. 318 335. doi: 10.1108/ITP-12-2018-0577.

Martin, C. L. (2016) 'Retrospective: compatibility management: customer-to-customer relationships in service environments', Journal of Services Marketing, 30(1), pp. 11-15. doi: 10.1108/JSM-10-2015-0319.

Mas-Machuca, M., Marimon, F. and Jaca, C. (2021) 'The unexplored potential of trust to boost customer loyalty for transport platforms', Research in Transportation Business \& Management, p. 100618. doi: https://doi.org/10.1016/j.rtbm.2021.100618.

McNally, R. C., Cavusgil, E. and Calantone, R. J. (2010) 'Product Innovativeness Dimensions and Their Relationships with Product Advantage, Product Financial Performance, and Project Protocol', Journal of Product Innovation Management, 27(7), pp. 991-1006. doi: https://doi.org/10.1111/j.1540-5885.2010.00766.x.

De Mendonca, T. R. and Zhou, Y. (2019) 'Environmental performance, customer satisfaction, and profitability: A study among large US companies', Sustainability, 11(19), p. 5418.

Menon, R. G. V. et al. (2016) 'Consumer attention to price in social commerce: Eye tracking patterns in retail clothing', Journal of Business Research, 69(11), pp. 5008-5013. doi: https://doi.org/10.1016/j.jbusres.2016.04.072.

Migliore, M., D'Orso, G. and Caminiti, D. (2020) 'The environmental benefits of carsharing: the case study of Palermo.', Transportation Research Procedia, 48, pp. 2127-2139. doi: https://doi.org/10.1016/j.trpro.2020.08.271.

Ming-Sung Cheng, J. et al. (2009) 'Why do customers utilize the internet as a retailing platform?', Asia Pacific Journal of Marketing and Logistics, 21(1), pp. 144-160. doi: $10.1108 / 13555850910926290$.

Mittendorf, C. (2018) 'Collaborative consumption: the role of familiarity and trust among Millennials', Journal of Consumer Marketing, 35(4), pp. 377-391. doi: 10.1108/JCM-122016-2040. 
Moeller, S. and Wittkowski, K. (2010) 'The burdens of ownership: reasons for preferring renting', Managing Service Quality: An International Journal, 20(2), pp. 176-191. doi: $10.1108 / 09604521011027598$.

Möhlmann, M. (2015) 'Collaborative consumption: determinants of satisfaction and the likelihood of using a sharing economy option again', Journal of Consumer Behaviour, 14(3), pp. 193-207. doi: https://doi.org/10.1002/cb.1512.

Mont, O. (2004) 'Institutionalisation of sustainable consumption patterns based on shared use', Ecological Economics, 50(1), pp. 135-153. doi: https://doi.org/10.1016/j.ecolecon.2004.03.030.

Moorman, C., Deshpandé, R. and Zaltman, G. (1993) 'Factors Affecting Trust in Market Research Relationships', Journal of Marketing, 57(1), pp. 81-101. doi: 10.1177/002224299305700106.

Morgan, R. M. and Hunt, S. D. (1994) 'The Commitment-Trust Theory of Relationship Marketing', Journal of Marketing, 58(3), pp. 20-38. doi: 10.2307/1252308.

Nahapiet, J. and Ghoshal, S. (1998) 'Social Capital, Intellectual Capital, and the Organizational Advantage', The Academy of Management Review, 23(2), pp. 242-266. doi: $10.2307 / 259373$.

Norman, A. T. and Russell, C. A. (2006) 'The Pass-Along Effect: Investigating Word-ofMouth Effects on Online Survey Procedures', Journal of Computer-Mediated Communication, 11(4), pp. 1085-1103. doi: https://doi.org/10.1111/j.10836101.2006.00309.x.

Nunnally, J. C. (1978) 'Psychometric theory’,New York: McGraw-Hill.

Nunnally, J. C. and Bernstein, I. H. (1995) Psychometric theory. New York: McGraw-Hill.

Oliveira, T., Tomar, S. and Tam, C. (2020) 'Evaluating collaborative consumption platforms from a consumer perspective', Journal of Cleaner Production, 273, p. 123018. doi: https://doi.org/10.1016/j.jclepro.2020.123018.

Oliver, R. L. (1997) Satisfaction : a behavioral perspective on the consumer. Boston, Mass.: Irwin/McGraw-Hill.

Ozbal, O., Duman, T. and Topaloglu, O. (2020) 'A trust-based peer-to-peer digital brand equity (P2P-DBE) model', Journal of Marketing Theory and Practice, 28(4), pp. 497-520. doi: 10.1080/10696679.2020.1794901.

Pavlou, P. A., Liang, H. and Xue, Y. (2007) 'Understanding and Mitigating Uncertainty in Online Exchange Relationships: A Principal-Agent Perspective', MIS Quarterly, 31(1), pp. 105-136. doi: 10.2307/25148783.

Peltier, J. W., Dahl, A. J. and Swan, E. L. (2020) 'Digital information flows across a $\mathrm{B} 2 \mathrm{C} / \mathrm{C} 2 \mathrm{C}$ continuum and technological innovations in service ecosystems: A servicedominant logic perspective', Journal of Business Research, 121, pp. 724-734. doi: https://doi.org/10.1016/j.jbusres.2020.03.020. 
Podsakoff, P. M. and Organ, D. W. (1986) 'Self-Reports in Organizational Research: Problems and Prospects', Journal of Management, 12(4), pp. 531-544. doi: 10.1177/014920638601200408.

Prentice, C., Dominique Lopes, S. and Wang, X. (2020) 'The impact of artificial intelligence and employee service quality on customer satisfaction and loyalty', Journal of Hospitality Marketing \& Management, 29(7), pp. 739-756. doi: 10.1080/19368623.2020.1722304.

Prud'homme, B. and Raymond, L. (2013) 'Sustainable development practices in the hospitality industry: An empirical study of their impact on customer satisfaction and intentions', International Journal of Hospitality Management, 34, pp. 116-126. doi: https://doi.org/10.1016/j.ijhm.2013.03.003.

Ram, S. and Jung, H.-S. (1990) 'The conceptualization and measurement of product usage', Journal of the Academy of Marketing Science, 18(1), pp. 67-76. doi: 10.1007/BF02729763.

Reisman, R., Payne, A. and Frow, P. (2019) 'Pricing in consumer digital markets: A dynamic framework', Australasian Marketing Journal (AMJ), 27(3), pp. 139-148. doi: https://doi.org/10.1016/j.ausmj.2019.07.002.

Resnick, P. et al. (2000) 'Reputation systems', Communications of the ACM, 43(12), pp. 4548.

Romanou, A. (2018) 'The necessity of the implementation of Privacy by Design in sectors where data protection concerns arise', Computer Law \& Security Review, 34(1), pp. 99-110. doi: https://doi.org/10.1016/j.clsr.2017.05.021.

Sarstedt, E. and Mooi, M. (2019) 'A Concise Guide to Market Research : The Process, Data, and Methods Using IBM SPSS Statistics'. Berlin, Heidelberg: Springer Berlin Heidelberg Imprint, Springer. Available at: https://doi.org/10.1007/978-3-662-56707-4.

Serra-Cantallops, A., Ramon-Cardona, J. and Salvi, F. (2018) 'The impact of positive emotional experiences on eWOM generation and loyalty', Spanish Journal of Marketing ESIC, 22(2), pp. 142-162. doi: 10.1108/SJME-03-2018-0009.

Simon, A. and Honore Petnji Yaya, L. (2012) 'Improving innovation and customer satisfaction through systems integration', Industrial Management \& Data Systems, 112(7), pp. 1026-1043. doi: 10.1108/02635571211255005.

Slee, T. (2017) What's yours is mine: against the sharing economy,OR Books. https://doi.org/10.2307/j.ctv62hf03

Spann, M. et al. (2018) 'Beyond Posted Prices: the Past, Present, and Future of Participative Pricing Mechanisms', Customer Needs and Solutions, 5(1), pp. 121-136. doi: 10.1007/s40547-017-0082-y.

Stephen, A. T. and Toubia, O. (2010) 'Deriving Value from Social Commerce Networks', Journal of Marketing Research, 47(2), pp. 215-228. doi: 10.1509/jmkr.47.2.215.

Stock, R. M. (2011) 'How does product program innovativeness affect customer satisfaction? A comparison of goods and services', Journal of the Academy of Marketing Science, 39(6), pp. 813-827. doi: 10.1007/s11747-010-0215-4. 
Sun, Y. et al. (2012) 'User Satisfaction with Information Technology Service Delivery: A Social Capital Perspective', Information Systems Research, 23(4), pp. 1195-1211. Available at: http://www.jstor.org/stable/42004252.

Tabibnia, G., Satpute, A. B. and Lieberman, M. D. (2008) 'The Sunny Side of Fairness: Preference for Fairness Activates Reward Circuitry (and Disregarding Unfairness Activates Self-Control Circuitry)', Psychological Science, 19(4), pp. 339-347. doi: 10.1111/j.14679280.2008.02091.x.

Täuscher, K. and Laudien, S. M. (2018) 'Understanding platform business models: A mixed methods study of marketplaces', European Management Journal, 36(3), pp. 319-329. doi: https://doi.org/10.1016/j.emj.2017.06.005.

Tenenhaus, M. et al. (2005) 'PLS path modeling', Computational statistics \& data analysis, 48(1), pp. 159-205.

Thakur, R. (2019) 'The moderating role of customer engagement experiences in customer satisfaction-loyalty relationship', European Journal of Marketing, 53(7), pp. 1278-1310. doi: 10.1108/EJM-11-2017-0895.

Thakur, R., Angriawan, A. and Summey, J. H. (2016) 'Technological opinion leadership: The role of personal innovativeness, gadget love, and technological innovativeness', Journal of Business Research, 69(8), pp. 2764-2773. doi: https://doi.org/10.1016/j.jbusres.2015.11.012.

Thompson, R., Compeau, D. and Higgins, C. (2006) 'Intentions to use information technologies: An integrative model', Journal of Organizational and End User Computing (JOEUC), 18(3), pp. 25-46.

Tran, V. et al. (2019) 'Travelers' Acceptance of Electric Carsharing Systems in Developing Countries: The Case of China', Sustainability . doi: 10.3390/su11195348.

Uber (2019). Annual report, available at: https://s23.q4cdn.com/407969754/files/doc_financials/2019/ar/Uber-Technologies-Inc-2019Annual-Report.pdf (accessed 18 August 2020)

Valenzuela, S., Park, N. and Kee, K. F. (2009) 'Is There Social Capital in a Social Network Site?: Facebook Use and College Students' Life Satisfaction, Trust, and Participation1', Journal of Computer-Mediated Communication, 14(4), pp. 875-901. doi: https://doi.org/10.1111/j.1083-6101.2009.01474.x.

Venkatesh, V. et al. (2003) 'User Acceptance of Information Technology: Toward a Unified View’, MIS Quarterly, 27(3), pp. 425-478. doi: 10.2307/30036540.

Venkatesh, V., Thong, J. Y. L. and Xu, X. (2012) 'Consumer Acceptance and Use of Information Technology: Extending the Unified Theory of Acceptance and Use of Technology', MIS Quarterly, 36(1), pp. 157-178. doi: 10.2307/41410412.

Vermeer, S. A. M. et al. (2019) 'Seeing the wood for the trees: How machine learning can help firms in identifying relevant electronic word-of-mouth in social media', International Journal of Research in Marketing, 36(3), pp. 492-508. doi: https://doi.org/10.1016/j.ijresmar.2019.01.010. 
Wagner, S. M., Grosse-Ruyken, P. T. and Erhun, F. (2012) 'The link between supply chain fit and financial performance of the firm', Journal of Operations Management, 30(4), pp. 340353. doi: https://doi.org/10.1016/j.jom.2012.01.001.

Wang, T. et al. (2016) 'What drives electronic word-of-mouth on social networking sites? Perspectives of social capital and self-determination', Telematics and Informatics, 33(4), pp. 1034-1047. doi: https://doi.org/10.1016/j.tele.2016.03.005.

Wang, W. and Wang, Y. (2020) 'Guest editorial', Information Technology \& People, 33(3), pp. 829-839. doi: 10.1108/ITP-06-2020-650.

Westbrook, R. A. (1987) 'Product/Consumption-Based Affective Responses and Postpurchase Processes', Journal of Marketing Research, 24(3), pp. 258-270. doi: $10.2307 / 3151636$.

Wilhelms, M.-P., Henkel, S. and Falk, T. (2017) 'To earn is not enough: A means-end analysis to uncover peer-providers' participation motives in peer-to-peer carsharing', Technological Forecasting and Social Change, 125, pp. 38-47. doi: https://doi.org/10.1016/j.techfore.2017.03.030.

Wirtz, J. et al. (2019) 'Platforms in the peer-to-peer sharing economy', Journal of Service Management, 30(4), pp. 452-483. doi: 10.1108/JOSM-11-2018-0369.

Wirtz, J. and Lwin, M. O. (2009) 'Regulatory Focus Theory, Trust, and Privacy Concern', Journal of Service Research, 12(2), pp. 190-207. doi: 10.1177/1094670509335772.

Wright, K. B. (2005) 'Researching Internet-Based Populations: Advantages and Disadvantages of Online Survey Research, Online Questionnaire Authoring Software Packages, and Web Survey Services', Journal of Computer-Mediated Communication, 10(3). doi: 10.1111/j.1083-6101.2005.tb00259.x.

Xu, X. and Lee, C. (2020) 'Utilizing the Platform Economy Effect Through EWOM: Does the Platform Matter?', International Journal of Production Economics, 227, p. 107663. doi: 10.1016/j.ijpe.2020.107663.

Zeithaml, V. A., Berry, L. L. and Parasuraman, A. (1996) 'The Behavioral Consequences of Service Quality', Journal of Marketing, 60(2), pp. 31-46. doi: 10.2307/1251929.

Zhang, M. et al. (2018) 'Effects of absorptive capacity, trust and information systems on product innovation'.International Journal of Operations \& Production Management, 38 No. 2, pp. 493-512. doi: 10.1108/IJOPM-11-2015-0687.

Zhuang, M., Cui, G. and Peng, L. (2018) 'Manufactured opinions: The effect of manipulating online product reviews', Journal of Business Research, 87, pp. 24-35. doi: https://doi.org/10.1016/j.jbusres.2018.02.016.

Zuo, W. et al. (2019) 'Service quality management of online car-hailing based on PCN in the sharing economy', Electronic Commerce Research and Applications, 34, p. 100827. doi: https://doi.org/10.1016/j.elerap.2019.100827. 
Appendix. Tables 3 and 6

Table III: Means, standard deviations and construct correlations $(N=501)$

\begin{tabular}{|c|c|c|c|c|c|c|c|c|c|c|c|c|c|}
\hline & Mean & SD & 1 & 2 & 3 & 4 & 5 & 6 & 7 & 8 & 9 & 10 & 11 \\
\hline 1 Age & 2.05 & 1.17 & 1.00 & & & & & & & & & & \\
\hline 2 Cost Saving & 5.45 & 1.39 & 0.54 & 1.00 & & & & & & & & & \\
\hline 3 eWOM & 3.90 & 2.28 & $0.50^{* *}$ & $0.68^{* * * *}$ & 1.00 & & & & & & & & \\
\hline 4 Environmental Impact & 4.56 & 1.59 & $0.44^{* *}$ & $0.68^{* * * *}$ & $0.59^{* * * *}$ & 1.00 & & & & & & & \\
\hline 5 Income & 1.57 & 1.34 & $0.76^{* * *}$ & $0.52^{* *}$ & $0.52^{* *}$ & $0.49^{* *}$ & 1.00 & & & & & & \\
\hline 6 Level of Education & 1.73 & 1.11 & $0.42^{* * * *}$ & $0.31^{* *}$ & $0.22^{* *}$ & $0.30^{* *}$ & $0.40^{* *}$ & 1.00 & & & & & \\
\hline $\begin{array}{l}7 \text { Perceived Technological } \\
\text { Innovativeness }\end{array}$ & 5.36 & 1.70 & $0.54^{* * *}$ & $0.86^{* * * *}$ & $0.77^{* * * *}$ & $0.64^{* * * *}$ & $0.54^{* * *}$ & $0.25^{* *}$ & 1.00 & & & & \\
\hline 8 Satisfaction & 5.13 & 1.45 & $0.48^{* * * *}$ & $0.87^{* * * *}$ & $0.65^{* * *}$ & $0.69^{* * * *}$ & $0.48^{* * *}$ & $0.29^{* *}$ & $0.84^{* * * *}$ & 1.00 & & & \\
\hline 9 Trust & 5.07 & 1.52 & $0.54^{* * *}$ & $0.86^{* * *}$ & $0.68^{* * * *}$ & $0.69^{* * *}$ & $0.54^{* * *}$ & $0.33^{* *}$ & $0.84^{* * *}$ & $0.80^{* * * *}$ & 1.00 & & \\
\hline 10 Utility & 4.92 & 1.39 & $0.36^{* *}$ & $0.69^{* * * *}$ & $0.53^{* * *}$ & $0.73^{* * * *}$ & $0.37^{* *}$ & $0.27^{* *}$ & $0.62^{* * * *}$ & $0.67^{* * * *}$ & $0.63^{* * *}$ & 1.00 & \\
\hline 11Usage Frequency & 3 & 1.12 & $0.42^{* *}$ & $0.73^{* *}$ & $0.61^{* * *}$ & $0.35^{* * *}$ & $0.33^{* * *}$ & $0.71^{* * * *}$ & $0.78^{* * * *}$ & $0.71^{* * * *}$ & $0.54^{* * *}$ & $0.55^{* * *}$ & 1.00 \\
\hline
\end{tabular}

$* * p<0.05$ (2-tailed).

$* * * p<0.01$ (2-tailed).

Note: $* * * p<0.01$ (2-tailed). 
Table VII: Significance of the path coefficients in the structural model and sub models (Bootstrapped at 5000 sample)

\begin{tabular}{|c|c|c|c|c|c|c|c|c|c|c|c|c|c|}
\hline & & & & 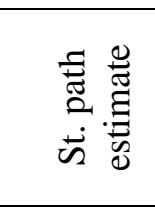 & 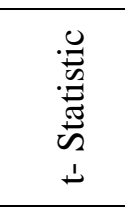 & $\begin{array}{l}\vec{F} \\
\overrightarrow{0} \\
\stackrel{0}{0} \\
\simeq\end{array}$ & 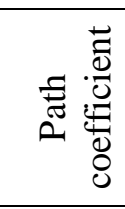 & 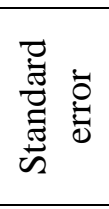 & $\begin{array}{l}\frac{\pi}{0} \\
\stackrel{0}{\pi} \\
\stackrel{7}{1}\end{array}$ & 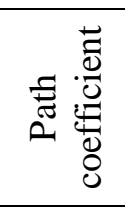 & 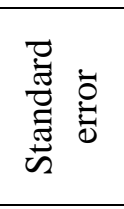 & $\begin{array}{l}\stackrel{0}{\Xi} \\
\stackrel{0}{\pi} \\
\stackrel{7}{7}\end{array}$ & 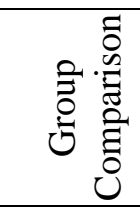 \\
\hline \multicolumn{4}{|c|}{ Hypotheses relationships } & \multicolumn{3}{|c|}{ Aggregated model } & \multicolumn{3}{|c|}{ Shared $(n=218)$} & \multicolumn{3}{|c|}{ Not Shared $(\mathrm{n}=283)$} & \\
\hline $\mathrm{H}_{1}$ & Trust & $>$ & \multirow{4}{*}{ Satisfaction } & $0.52 * * *$ & 11.29 & Supported & 0.43 & 0.02 & $11.66^{* * *}$ & 0.55 & 0.04 & $1.79 * *$ & $1.38^{\mathrm{NS}}$ \\
\hline $\mathrm{H}_{2}$ & Environmental Impact & $>$ & & 0.03 & 0.95 & Not Supported & 0.04 & 0.05 & $1.21^{\mathrm{NS}}$ & 0.07 & 0.12 & $1.66^{\mathrm{NS}}$ & $0.52^{\mathrm{NS}}$ \\
\hline $\mathrm{H}_{3}$ & Cost Saving & $>$ & & $0.35 * * *$ & 7.65 & Supported & 0.43 & 0.07 & $8.55 * * *$ & 0.32 & 0.10 & $6.23 * * *$ & $3.58 * * *$ \\
\hline $\mathrm{H}_{4}$ & Utility & $>$ & & 0.07 & 1.27 & Not Supported & 0.17 & 0.04 & $2.07^{\mathrm{NS}}$ & 0.03 & 0.06 & $1.22^{\mathrm{NS}}$ & $0.95^{\mathrm{NS}}$ \\
\hline $\mathrm{H}_{5}$ & Satisfaction & $>$ & eWOM & $0.47 * * *$ & 9.55 & Supported & 0.67 & 0.04 & $22.36 * * *$ & 0.42 & 0.08 & $5.51 * * *$ & $9.69 * * *$ \\
\hline \multicolumn{4}{|c|}{ Moderating effect } & & & & \multicolumn{3}{|c|}{ Age $<35(n=332)$} & \multicolumn{3}{|c|}{ Age $\geq 35(n=169)$} & \\
\hline $\mathrm{H}_{6}$ & $\begin{array}{l}\text { Perceived } \\
\text { Technological } \\
\text { Innovativeness }\end{array}$ & $>$ & \begin{tabular}{|c} 
Satisfaction \\
$*$ \\
eWOM \\
\end{tabular} & $0.71 * * *$ & 13.04 & Supported & 0.72 & 0.06 & 10.61 & 0.55 & 0.09 & 5.97 & $3.35 * * *$ \\
\hline \multicolumn{4}{|c|}{ Group Analysis (1) } & & & & \multicolumn{3}{|c|}{ Age $<35(n=332)$} & \multicolumn{3}{|c|}{ Age $\geq 35(n=169)$} & \\
\hline $\mathrm{H}_{1}$ & Trust & $>$ & Satisfaction & & & & 0.50 & 0.04 & 10.04 & 0.55 & 0.08 & 6.55 & $8.25^{* * *}$ \\
\hline $\mathrm{H}_{3}$ & Cost Saving & $>$ & Satisfaction & & & & 0.38 & 0.07 & 7.60 & 0.24 & 0.05 & 3.04 & $5.98 * * *$ \\
\hline \multicolumn{4}{|c|}{ Group Analysis (2) } & & & & \multicolumn{3}{|c|}{ Usage Frequency $($ High $n=412)$} & \multicolumn{3}{|c|}{ Usage Frequency $($ Low $n=89)$} & \\
\hline $\mathrm{H}_{1}$ & Trust & $>$ & Satisfaction & & & & 0.32 & 0.01 & 12.50 & 0.24 & 0.06 & 4.50 & $4.80 * * *$ \\
\hline $\mathrm{H}_{3}$ & Cost Saving & $>$ & Satisfaction & & & & 0.41 & 0.02 & 17.55 & 0.30 & 0.05 & 6.35 & $9.65 * * *$ \\
\hline
\end{tabular}




\begin{tabular}{|l|l|l|l|l|l|l|l|l|l|l|l|}
\hline $\mathrm{H}_{5}$ & Satisfaction & $>$ & eWOM & & 0.52 & 0.01 & 19.40 & 0.38 & 0.05 & 8.52 & $7.42^{* * *}$ \\
\hline
\end{tabular}

a (error probability for one-tailed t-test).

${ }^{N S}$ Path is not significant.

$* * \mathrm{p}<0.05$

$* * * \mathrm{p}<0.001$ 